This is the peer reviewed version of the following article: Bertoldi, W., Gurnell, A.M., 2020. Physical engineering of an island-braided river by two riparian tree species: evidence from aerial images and airborne lidar. River Research and Applications, which has been published in final form at DOI: 10.1002/rra.3657. This article may be used for non-commercial purposes in accordance with Wiley Terms and Conditions for Self-Archiving

\title{
Physical engineering of an island-braided river by two riparian tree species: evidence from aerial images and airborne lidar
}

\author{
Walter Bertoldi ${ }^{1^{*}}$ and Angela M. Gurnell ${ }^{2}$ \\ ${ }^{1}$ Department of Civil, Environmental and Mechanical Engineering, University of Trento, Via \\ Mesiano 77, 38123 Trento, Italy \\ ${ }^{2}$ School of Geography, Queen Mary University of London, London E1 2NS, U.K. \\ * corresponding author: Walter Bertoldi, email: walter.bertoldi@unitn.it
}

\section{ABSTRACT}

Following a review of the European distribution, habitat requirements and life history characteristics of two riparian tree species, Alnus incana (L.) Moench. (grey alder, a member of the Betulaceae family) and Populus nigra L. (black poplar, a member of the Salicaceae family), we explore their changing spatial distribution and topographic position within a $7 \mathrm{~km}$, island braided reach of the Tagliamento River, Italy, where Populus nigra dominates the woody vegetation cover. Combining field observations and information extracted from aerial images, airborne lidar data, and river flow time series for the period 1986 to 2017, we investigate (i) the changing spatial distribution of all ( $P$. nigra-dominated) woody vegetation and of $A$. incana alone, (ii) whether river bed topography can be associated with these changing spatial distributions, and (iii) we consider whether $A$. incana displays any particular characteristics in its spatial and topographic distribution that may indicate that it is complementing the physical engineering role of $P$. nigra. We show that $A$. incana predominantly grows in lines along channel, island and floodplain edges, bordering wooded areas dominated by $P$. nigra and that areas supporting $A$. incana are associated with the topographic development of the river bed. We conclude that $A$. incana appears to be acting as a complementary physical engineer to P. nigra, suggesting that similar complementary physical engineering of river beds may be achieved by species with different life history traits to influence landform development in other river environments. 


\section{KEY WORDS}

Riparian vegetation, Ecosystem engineering, Island development, Alnus incana, Populus nigra

\section{INTRODUCTION}

'Riparian zones are the interfaces between terrestrial and aquatic systems' (Gregory et al., 1991), which we interpret to include the river channel bed and margins above the level of typical low flows and the active floodplain that is regularly inundated by the contemporary flow regime. These areas are morphologically complex and dynamic, responding and adapting to fluvial disturbances and supporting a mosaic of physical habitats (Naiman et al., 2005) from ponds and exposed bare sediments through sparse to heavily vegetated areas with widely varying sediment calibre and stratigraphy, groundwater regimes, and susceptibility to inundation and drought (Gurnell and Petts, 2011). In these dynamic landscapes, the presence and survival of plants is defined by life history traits that support colonisation and establishment under highly disturbed conditions (e.g. Mahoney and Rood, 1998; Johnson, 2000; Polzin and Rood, 2006; Bornette et al., 2008). Riparian environments represent the most diverse and productive ecosystems on earth, and an increased understanding of their functioning is crucial for their sustainable management (Tockner and Stanford, 2002) particularly within the context of global environmental change (Kominoski et al., 2013; Van Looy and Piffady, 2017).

Over the last two decades, the ways in which riparian plants respond to physical disturbances and constraints and also influence river morphodynamics has received increasing attention (Corenblit et al., 2007; Gurnell et al., 2012; Polvi and Wohl, 2013; Gurnell, 2014). In particular, certain 'engineer' species are now recognised to modulate materials, resources and energy flows, influencing the creation and maintenance of fluvial landforms and associated ecological successions (e.g. Kollmann et al., 1999; Gurnell et al., 2001, 2016; Corenblit et al., 2007, 2009, Tabacchi et al., 2019). Building on knowledge of life history and ecological characteristics (Karrenberg et al., 2002), much research has focused on the role of Salicaceae species in initiating, building and sustaining landforms (Gurnell et al., 2005; Francis et al., 2009; Corenblit et al., 2009) and thus creating a topographic signature of vegetation development across river beds and margins (Bertoldi et al., 2011b; Bywater-Reyes et al., 2017). Research has also revealed the biomechanical properties of the Salicaceae that allow this family to survive, to retain fluvial sediments and to build and reinforce landforms (e.g. Imada et al., 2008; Scippa et al., 2008; Pasquale et al., 2012; Bankhead et al., 2017; Holloway et al., 2017 a, b, c; Wintenberger et al., 2017). 
Recently, Hortobágyi et al. (2018) explored the engineering roles of three Salicaceae species, Populus nigra, Salix purpurea and Salix alba along the Allier River, France. They observed that $P$. nigra is the main engineer species influencing bar scale landform development, whereas S. purpurea and S. alba, respectively, influence sediment retention on the most exposed parts of bars and on the more sheltered areas of the bar tail. Thus, the three species perform complementary roles reflecting their different but also overlapping spatial patterns of establishment and biogeomorphic feedbacks on river bars.

In this paper, we aim to extend previous research on ecosystem engineering by riparian trees belonging to the Salicaceae family by focusing on two riparian tree species drawn from different families: Alnus incana (L.) Moench. (grey alder, a member of the Betulaceae family) and Populus nigra L. (black poplar, a member of the Salicaceae family). Since much previous research has explored the physical ecosystem engineering role of the riparian Salicaceae in general and $P$. nigra in particular, we place greater emphasis on A. incana. Following a review of the European distribution, habitat requirements and life history characteristics of both species, we introduce a $7 \mathrm{~km}$, islandbraided study reach of the Tagliamento river, Italy (Figure 1), where P. nigra is the dominant riparian tree species but where we have observed an increase in the cover of $A$. incana over the last two decades. Using information for three areas within the study reach extracted from field observations and a range of historical sources (river flow time series, aerial imagery, airborne lidar data), we pursue three research aims:

RESEARCH AIM 1: To establish the changing spatial distribution of all (P. nigra-dominated) woody vegetation and of $A$. incana alone.

RESEARCH AIM 2: To investigate whether river bed topography can be associated with the changing spatial distribution of all woody vegetation and of $A$. incana, alone.

RESEARCH AIM 3: To interpret and discuss results from the above lines of evidence to consider whether A. incana displays any particular characteristics in its spatial and topographic distribution that may indicate that it is complementing the physical engineering role of $P$. nigra.

\section{EUROPEAN DISTRIBUTION, HABITAT AND LIFE HISTORY CHARACTERISTICS OF ALNUS INCANA AND POPULUS NIGRA}

Houston Durrant et al. (2016) and de Rigo et al. (2016), respectively, map the natural European distribution of $A$. incana and P. nigra. Alnus incana extends across Scandinavia and Poland into Russia, covers much of central Europe and the Alps, and extends eastwards along the Carpathian 
and Balkan mountains and the Dinaric Alps. A single sub-species of $A$. incana (Alnus incana ssp. incana) is native to Europe (Wilson et al., 2018) and remains quite common within its native range. The native range of $P$. nigra extends from England and Wales across Germany, Poland and into Russia in the north, to the north African coast in the south, and from the Iberian peninsula in the west across central and southern Europe into Turkey in the east. $P$. nigra is highly threatened within Europe because of habitat degradation and lack of genetic diversity.

Data from Houston Durrant et al. (2016) indicate that within Europe A. incana occupies areas whose average annual temperature is between $-2{ }^{\circ} \mathrm{C}$ and $+9{ }^{\circ} \mathrm{C}$, average temperature in the coolest month is between $-15^{\circ} \mathrm{C}$ and $+2{ }^{\circ} \mathrm{C}$, and annual precipitation is between 500 and $3000 \mathrm{~mm}$. Data from de Rigo et al. (2016) indicate that $P$. nigra occupies areas whose average annual temperature is between $+6{ }^{\circ} \mathrm{C}$ to $+17^{\circ} \mathrm{C}$, average temperature in the coolest month is between $-5^{\circ} \mathrm{C}$ and $+10{ }^{\circ} \mathrm{C}$, and annual precipitation falls between 300 and $1300 \mathrm{~mm}$.

The following descriptions of habitat requirements and life history traits that may support the two species in colonising and engineering river beds synthesise information for $A$. incana from Rytter (1996), Rytter et al. (2000), Roy et al. (2007), Chapin et al. (2016), Houston Durrant et al. (2016) and Wilson et al. (2018) and for P. nigra from Barsoum (2001), Chiatante et al. (2010), Guilloy-Froget et al. (2002, 2011), Karrenberg et al. (2002), Imbert and Lefèvre (2003), Karrenberg and Suter (2003), Francis and Gurnell (2006), Francis (2007), Moggridge and Gurnell (2009), Gurnell (2016), Holloway et al. (2017 a, b), Wintenberger et al. $(2017,2019)$.

Both are pioneer species that can rapidly colonise areas of bare ground. Alnus incana prefers moist and nutrient rich sites but is able to grow on poorer, moderately dry sites. Populus nigra colonises open, bare riverine sediments. Moisture availability and lack of shade are the most important initial environmental conditions. Thereafter, a sustained moisture supply and lack of disturbance are important for early root and shoot growth. During inundation, young seedlings of both species are susceptible to disturbance from high flow velocities as well as sediment erosion and burial.

Based largely on observations from plantations, $A$. incana establishes from seeds, root suckers and stump sprouts, but is less likely to reproduce asexually than P. nigra during the early years of growth, although flood damage may encourage earlier sucker and root stump shoots in a similar manner to that reported for regrowth following plantation coppicing. Seed production commences at around 6 to 15 years. Observations for $P$. nigra are mainly drawn from riparian environments, where the species establishes from seeds, root suckers and stump sprouts but, unlike $A$. incana, sprouting and sucker development occur from an early age in response to burial and plant damage. The species 
regenerates from vegetative fragments of all sizes if environmental conditions are suitable. Seed production commences at an age of 6 to 10 years.

Alnus incana flowers in early spring, releasing small $(1-2 \mathrm{~mm})$ seeds between September and October. Seeds are dispersed up to $30 \mathrm{~m}$ by wind and over much longer distances by water. Seeds readily germinate under suitable conditions but are also easy to store (Gosling, 2007), with some evidence that they form a short-term persistent seed bank (seeds remain viable for at least 1 year) (Thompson et al., 1997). Populus nigra flowers in spring and the small, light seeds (approximately 1500 seeds per g) are dispersed long distances by wind and water over 2 to 12 weeks in spring and early summer. Salicaceae seeds are currently impossible to store (Gosling, 2007). Karrenberg and Suter (2003) determined a half-viability period for P. nigra seeds in dry storage of around 23 days.

Maximum growth rates for $A$. incana occur within the first 10 to 20 years, and mature trees can reach a height of $25 \mathrm{~m}$ with a lifespan of 60 to 100 years. Establishment and growth of $P$. nigra is highly sensitive to moisture availability and depth to groundwater. Along the Tagliamento river, shoots from seedlings, cuttings and uprooted trees show typical daily growth rates of 1, 2 and 10 $\mathrm{mm}$, respectively, in their first growing season, and average annual vertical growth increments for 2 to 24 year trees show a logarithmic increase with age from around 0.5 to $>1 \mathrm{~m}$ (Gurnell, 2016). Trees can reach a height of $40 \mathrm{~m}$.

In summary, P. nigra and A. incana show differences in their life history traits and environmental requirements, which are relevant to the present research aims because they may translate into different spatial distributions and different styles of influence on the topographic development of the river bed.

\section{STUDY AREA}

The $7 \mathrm{~km}$ long, study reach of the Tagliamento river, NE Italy, (Figure 1) has a downstream gradient of $0.0036 \mathrm{~m} \cdot \mathrm{m}^{-1}$ and a braid plain up to $800 \mathrm{~m}$ wide which contains numerous wooded islands. Island riparian woodland is dominated by $P$. nigra, although other Salicaceae species are present, notably Salix alba, S. daphnoides, S. elaeagnos, S. purpurea and S. triandra. Alnus incana is also widely observed within the study reach, although our interest in this species was stimulated by an apparent increase in its cover over the last two decades. Furthermore, although the role of $P$. nigra as a physical ecosystem engineer, driving island development along the Tagliamento has been widely reported (e.g. Gurnell et al. 2005, 2019, Gurnell and Petts, 2002, 2006, Francis et al., 2009, Gurnell, 2016, Zen et al., 2017), the role of $A$. incana is unknown. 
In a survey of woody vegetation along the main stem of the Tagliamento river, Karrenberg et al.

(2003, Figure 2) established that $A$. incana is confined to the upper and middle reaches of the river while $P$. nigra is present through the middle and lower reaches. The study reach marks the most downstream location of $A$. incana recorded by Karrenberg et al. (2003) at a transect located $75 \mathrm{~km}$ from the river's source (Figure 1), whereas $P$. nigra was observed both upstream and downstream, although at the study reach it showed a major expansion in its basal area (i.e. both its abundance and size).

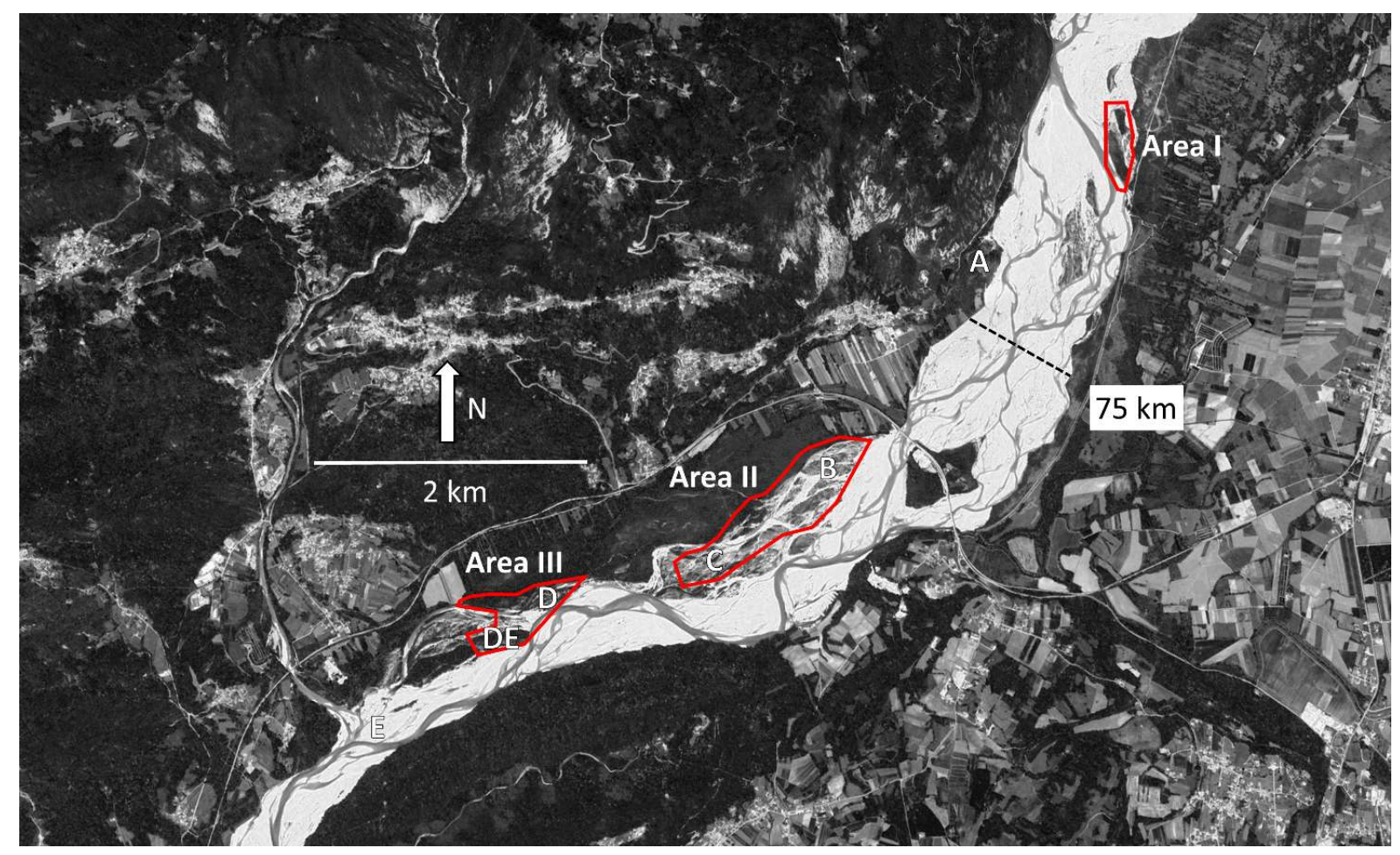

Figure 1: The study reach showing areas I, II and III where field surveys were conducted in 2019, the transect at $75 \mathrm{~km}$ from source where Karrenberg et al. (2003) undertook field measurements, and survey locations A, B, C, D, DE and E where field measurements were collected within the study reach in 2007. (The image was downloaded from Google Earth, image@2019 Maxar Technologies). Flow is from North East (top right) to South West (bottom left).

The suitability of the local climate for both species can be assessed by reference to a climatological station at Osoppo, which is located on the floodplain, $3 \mathrm{~km}$ from the study reach. Here, the average annual precipitation (1326 $\mathrm{mm}$ ) is within the European range occupied by $A$. incana and close to the maximum observed for $P$. nigra (see previous section), the average annual temperature $\left(+12.0^{\circ} \mathrm{C}\right.$ ) is $3{ }^{\circ} \mathrm{C}$ above the range typical for $A$. incana and the coolest month temperature $\left(+2.2^{\circ} \mathrm{C}\right)$ is close to the maximum observed for this species, whereas the local minimum and average temperatures are at 
the centre of the European range occupied by $P$. nigra (Osoppo climate data downloaded from https://en.climate-data.org/europe/italy/friuli-venezia-giulia/osoppo-113897 on 7 August 2019).
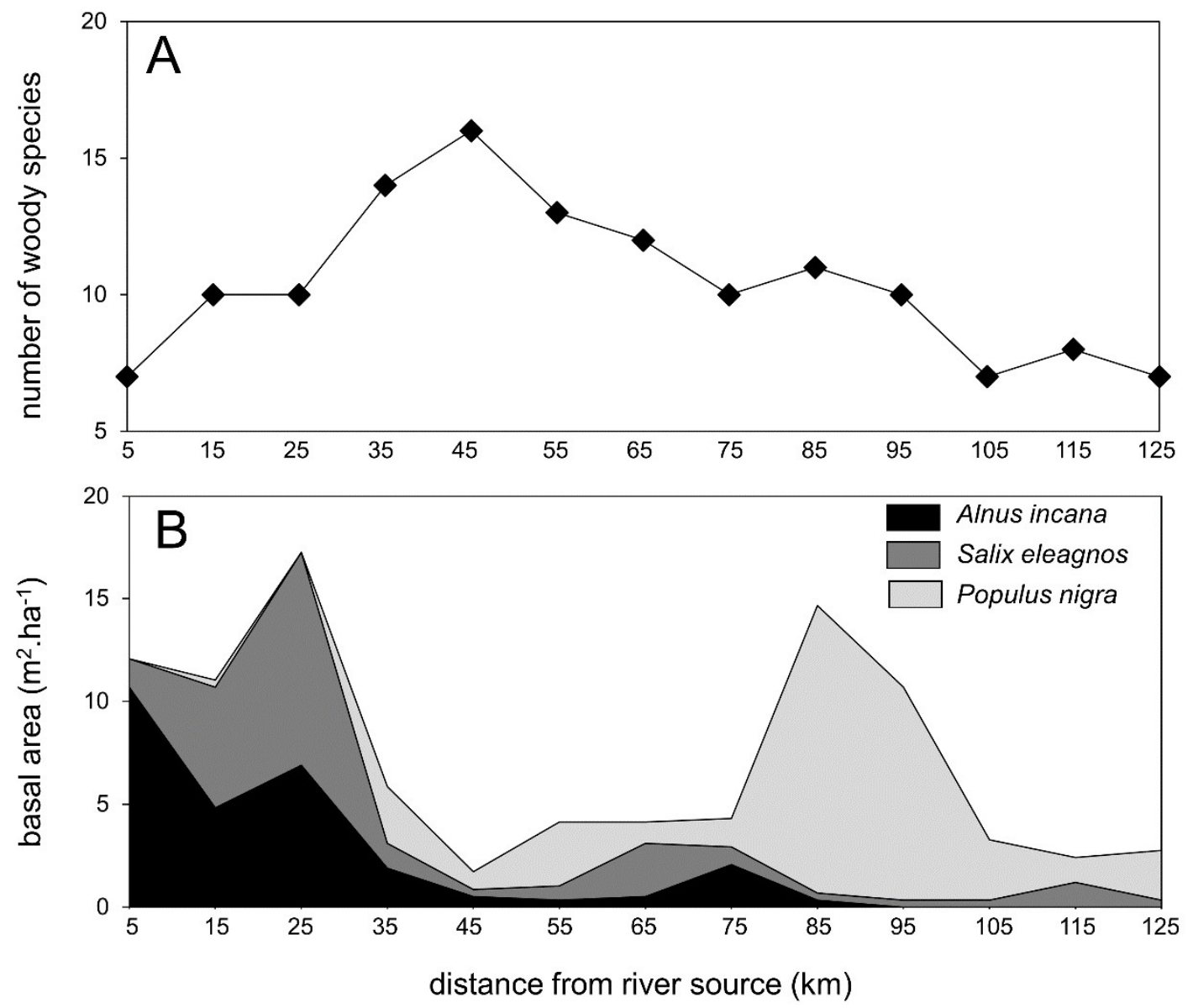

Figure 2: Number of woody species and cumulative basal area of the three most common species observed at sites spaced at $10 \mathrm{~km}$ intervals along the main stem of the Tagliamento in summer 1999 (data from Karrenberg et al., 2003).

Thus, the study reach is located at the downstream limit of $A$. incana along the Tagliamento and has a temperature regime that is close to the limits of $A$. incana's natural European range. In contrast, $P$. nigra is the dominant riparian tree species both upstream and downstream of the study reach, and the study reach offers a temperature regime that is at the centre of the European range occupied by P. nigra.

METHODS

Data Sources 
A variety of data sources were used to support analyses directed at research aims 1 and 2, and to provide the bases for discussion of research aim 3.

Literature

Understanding tree growth performance is critical to addressing research aim 1 as well as building links between evidence extracted from spatial (field observations, aerial images, lidar surveys) and temporal (flow time series) data sources, to address research aims 2 and 3 . While $P$. nigra is the dominant tree species throughout the woodland of the study reach, allowing this species' spatial encroachment to be established simply from the extent of all woody vegetation cover, and its growth performance within the study reach is already established (Gurnell, 2016), neither of these properties are established for $A$. incana.

One source of $A$. incana growth performance information is the published literature, from which observations of the height, stem diameter and age of $A$. incana were extracted for a number of sites within Europe.

\section{Field Observations}

The growth performance of $A$. incana was also investigated within the study reach, as well as establishing the spatial distribution of the species to contribute to research aim 1.

Growth performance was investigated in September 2007. Islands were searched at six locations distributed in an upstream to downstream sequence through the reach to capture any impacts of downstream variations in the growing environment. Each location was searched for 10 specimens of A. incana taller than $4 \mathrm{~m}$. None were found at the most upstream (A) and downstream (F) locations, two individuals were located at B ( 8 additional smaller trees were sampled), ten were located at each of $C, D$ and $E$, and the tallest alder individuals observed during the survey were found between sites $D$ and $E$ (DE, Figure 1 ) where 5 additional trees were sampled. At the time of this survey it was difficult to find ten $A$. incana individuals that were taller than $4 \mathrm{~m}$ at any location, although shorter trees were observed, particularly at C, D, DE and E. The following measurements were collected for the 45 sampled trees ( $38>4 \mathrm{~m}$ tall): stem diameter and age (count of annual growth rings) at 1 to 1.3 $\mathrm{m}$ above the ground surface, and height (estimated from scaled photographs).

The spatial distribution of all alder trees taller than $4 \mathrm{~m}$ and the size of the tallest individuals were recorded in March 2019 in three areas of the study reach $\left(1--132,000 \mathrm{~m}^{2}, \mathrm{II}-560,000 \mathrm{~m}^{2}, \mathrm{III}-\right.$ 
221,000 m²; Figure 1). These areas enclosed 2007 survey sites B, C, D and DE. All islands at 2007 survey sites $A$ and $E$ and around the transect at $75 \mathrm{~km}$ from the river's source (Figure 1) that was explored by Karrenberg et al. (2003) had been removed by fluvial erosion and so could not be included in this field survey. Areas I, II and III were searched for A. incana $>4 \mathrm{~m}$ in height and the locations of over 600 trees were recorded using a hand-held GPS. Where alder trees were closely spaced, sufficient trees were recorded to capture locations at a minimum $10 \mathrm{~m}$ spacing. In addition, scaled photographs (to estimate tree height) and stem diameter measurements were collected for 69 of the tallest alder trees.

\section{Secondary Data}

Secondary sources provided information on the spatial distribution of all (P. nigra-dominated) woody vegetation cover (research aim 1) and the topography of the river bed at different dates, allowing the temporal development of vegetation cover (research aim 1) and bed topography (research aim 2) to be established.

The spatial extent and height of woody vegetation and the topography of the river bed were extracted from three airborne lidar surveys (May 2005, August 2010, October 2013; average point density per $\mathrm{m}^{2}$, respectively, 1, 4 and 10 ), providing complete coverage of areas I, II and III, apart from the upstream half of area II, which was missing from the 2010 survey and only 50\% covered by the 2013 survey. Rectified aerial images from 1986, 1993, 1997, 2003, 2005, 2010, 2011, 2013 and 2017 (resolution ranged from approximately $1.5 \mathrm{~m}$ (earliest) to $0.2 \mathrm{~m}$ (latest images)) visualised the changing positions and spatial extent of the river bar and channel network and wooded areas over four decades.

A river stage record from a station approximately $3 \mathrm{~km}$ downstream of the study reach (Figure 3) allowed information extracted from the spatial sources to be placed into their temporal hydrological context. All events exceeding a stage of $3 \mathrm{~m}$ (black and white arrows) indicate a bankfull flood within the study reach (Bertoldi et al., 2009) and thus an event capable of significant channel-bed vegetation and landform disturbance. In particular, we focus on events in November 1990, June and November 1996, November 2000 and October 2004 (black arrows, Figure 3) because they are all large events that are sufficiently old for any surviving vegetation to be well established at the time of the field survey in 2019 and because aerial images are available before, between and after these events (i.e. 1986, 1993, 1997, 2003, 2005), allowing interpretation of locations of vegetation cover change. 


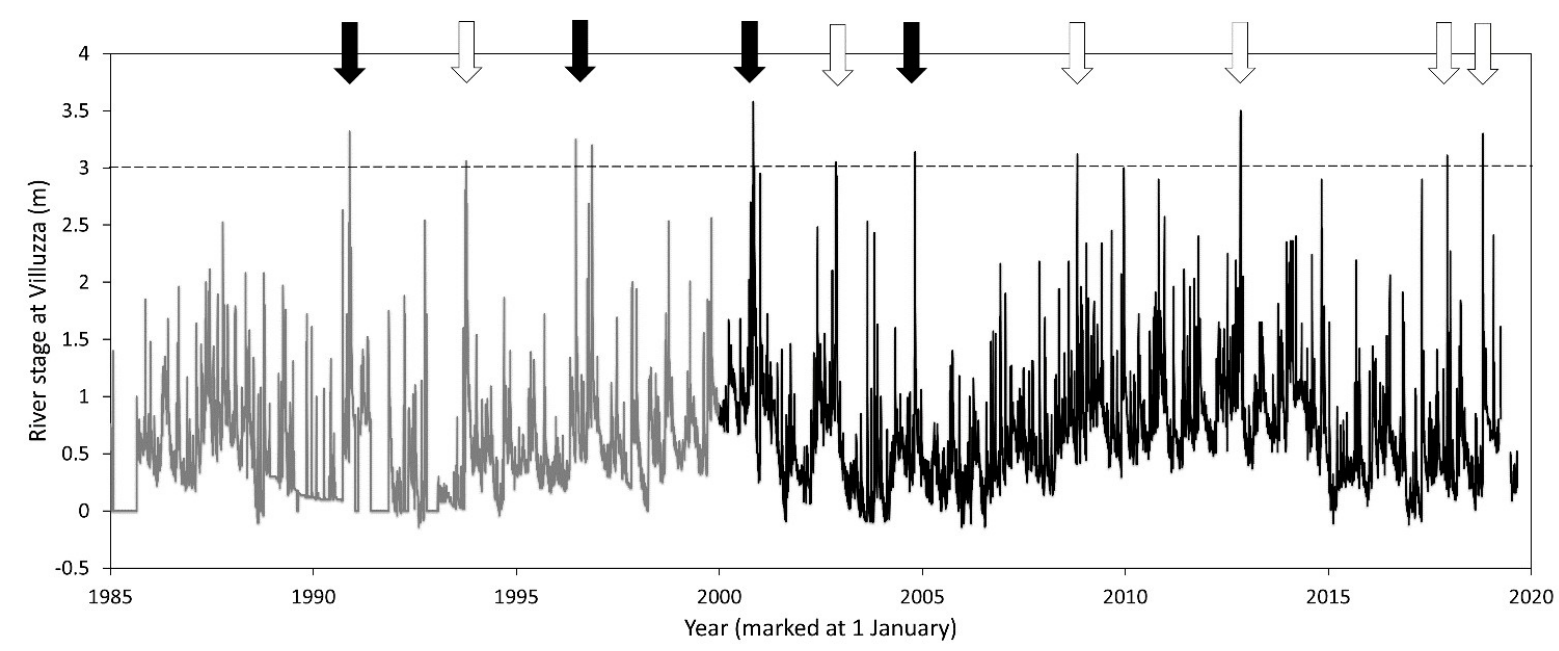

Figure 3: Daily river stage record, 1985 to present, at the Villuzza station (located $3 \mathrm{~km}$ downstream from the study reach). The record after 2000 (black line) represents the daily maximum stage extracted from 30 minute observations. The precise nature of the record before 2000 (grey line) is unknown but probably varies between single observations within a day and the highest observation within a day (where the number of observations within a day is highly variable). Arrows indicate floods exceeding the approximate level of bankfull (stage $=3 \mathrm{~m}$ ) with black arrows denoting the four floods discussed in detail and white arrows denoting other floods with a stage exceeding $3 \mathrm{~m}$.

\section{Data Analysis}

\section{Field Observations}

While the changing extent of $P$. nigra can be estimated from the extent of the entire woody vegetation cover in aerial images, a measure of growth performance is critical to unravelling when the $A$. incana individuals mapped in 2019 may have started to grow. Growth performance of $A$. incana was estimated from the 2007 and 2019 field measurements of the largest individual alder trees and data extracted from the published literature, including relationships among height, stem diameter, age and growth performance.

To further investigate the changing spatial distribution of $A$. incana, the 2019 GPS locations of alder trees were entered into a GIS along with the rectified image and lidar data sets. The positional accuracy of the GPS locations for isolated trees was found to be approximately $5 \mathrm{~m}$, judged from the positions of the same trees on the most recent images and lidar surveys. Where locations of individual trees were clear on recent image and lidar evidence, the GPS locations were adjusted to the centre of the canopy of the relevant tree. Circular polygons of $5 \mathrm{~m}$ radius were then centred on 
all the surveyed points and where these circles overlapped, areas or lines of trees were interpolated between the surveyed points to visualise spatial patterns in their distributions. The distribution of alder trees surveyed in 2019 was compared with the distribution of all woody vegetation in historical images, to identify when the locations occupied by each alder tree became vegetated.

Aerial Images

To further contribute to research aim 1, reconstructions of the evolution of all ( $P$. nigra-dominated) woody vegetation cover and also the field-observed alder were achieved using the historical sequence of aerial images (1986 to 2017). The colonisation and subsequent growth of $A$. incana within areas I, II and III were interpreted by overlaying the points, lines and areas occupied by alder in 2019 on the rectified historical images.

Lidar Data

Following Bertoldi et al. (2011b), the lidar data were classified into terrain and vegetation. Digital Elevation Models (DEMs) were estimated for the underlying terrain. The longitudinal slope of the river bed was estimated by computing a moving average of bed elevation (excluding areas beyond the braid plane) within an $800 \mathrm{~m}$ square window. Average elevation within each window was calculated and a surface corresponding to the downstream slope at average elevation was subtracted from each DEM to yield a detrended DEM (independent of downstream slope). Vegetation height was interpolated as the difference between the interpolated ground surface DEM and the lidar point cloud. Lidar data were used in three ways to investigate the height, growth performance, geographical (research aim 1) and topographic position (research aim 2) of alders within areas I, II and III.

First, relationships between tree height and growth rate were explored to establish the growth performance of $A$. incana. Forty-six isolated alder trees observed during the 2019 field survey were identified within the 2013 lidar data set. Nineteen of these trees were present and their height could be extracted from the 2005, 2010 and 2013 lidar data sets, allowing their average annual growth increment to be estimated between 2005 and 2013 ( 8 years) and 2005 and 2010 (5 years). These data were used to estimate relationships between tree growth performance, height and age, and to define height ranges that might be achieved by $A$. incana colonising the reach before or following three flood events (1996, 2000, 2004, Figure 3). The 1990 flood was not included in this analysis because of the limited data for sufficiently old trees. Growth performance information extracted 
from the 2007 field data set was used to sanity-check the lidar-derived estimates of growth rate in relation to tree height and age (see Supplementary Material).

Second, we extracted the height of the entire woody vegetation canopy taller than $1 \mathrm{~m}$ on a $2 \mathrm{~m}$ resolution grid and the maximum canopy height within a $1.5 \mathrm{~m}$ radius around all locations of alder recorded in the field in 2019. At the same locations, we also extracted the detrended ground elevation from all three lidar data sets. We then constructed relative (proportional) frequency distributions of the detrended elevation of the river bed along the entire study reach and also relative detrended elevation frequency distributions for the ground surface under the alder trees mapped in 2019 and under all woody vegetation within areas I, II and III for all lidar surveys (2005, 2010, 2013). In this way the changing height (age) of all woody vegetation and of the 2019 observed A. incana individuals could be linked to changes in the morphology of the underlying river bed providing a basis for any distinctive topographic signatures to be identified.

Third, we also subdivided the alder locations and locations under all woody vegetation into four canopy height classes, reflecting likely thresholds of growth for alder trees that developed following the floods in 1996, 2000 and 2004 (Figure 3, $<5 \mathrm{~m}, 5-<8 \mathrm{~m}, 8-<10 \mathrm{~m}$ and $>10 \mathrm{~m}$ ). We applied these classes to the proportional frequency distributions of detrended bed elevation described above to link trees of different size classes to their topographic position. This allowed a more detailed analysis of the links between flood disturbances, alder colonisation and growth, and the development of river bed morphology, potentially distinguishing unique patterns linked to any physical engineering of the river bed by $A$. incana.

\section{RESULTS}

\section{Growth performance of $A$. incana}

We base our analysis of $A$. incana dynamics in the study reach entirely on growth performance estimates from lidar data. However, we used field measurements collected in 2007 and published data (Huss-Danell and Lundmark, 1988; Aosaar and Uri, 2008; Johansson, 2005; Uri et al., 2009, 2014, 2017; Krzaklewski et al., 2012, Wilson et al., 2018) to check that the lidar estimates were robust. For reasons of space economy, we present these data sets and their analysis in Supplementary Material and summarise the results below.

The 2007 field estimates of annual growth increment fall in the lower half of the published range for A. incana of the same age (Supplementary Material Figures IA and IB). Field measurements of tree height plotted against diameter in 2007 and 2019 show a consistent trend, but the 2019 
measurements are generally taken from taller trees (evidence of an increase in the size of the largest trees between the two survey dates) and the Tagliamento trees are shorter than published data for the same stem diameter (Supplementary Material Figures IC and ID).

When tree heights are plotted against estimates of annual average growth increment, there is good overlap between lidar estimates and 2007 field estimates (Supplementary Material Figure IIA). Using only the lidar data, a fixed growth increment of $0.6 \mathrm{~m} . \mathrm{yr}^{-1}$ (Supplementary Material Figure IIB, approximating the median and mean lidar estimated growth rates of 0.63 and $0.59 \mathrm{~m} \cdot \mathrm{yr}^{-1}$ ) was compared with estimates based on a best-fit logistic function that emulated the S-shaped curve commonly described by tree growth (Supplementary Material Figure IIB, Tsolaris and Wallace, 2002; Camporeale and Ridolfi, 2006). When we used the fixed rate of $0.6 \mathrm{~m} \cdot \mathrm{yr}^{-1}$ and the estimated logistic function to separate observations of alder across areas I, II and III into trees that probably postdated three of the four flood events in our study period in 1996 (17 years before the 2013 lidar survey), 2000 (13 years before the 2013 lidar survey) and 2004 (9 years before the 2013 lidar survey), both methods gave similar results: trees of 17,13 and 9 years of age would be 10.2, 7.8 and $5.4 \mathrm{~m}$ tall or 10.2, 7.6 and $4.7 \mathrm{~m}$ tall, respectively. Therefore, we selected approximate height thresholds of 10,8 and $5 \mathrm{~m}$ to explore spatial distributions of alder of different age and their potential association with flood disturbance events.

\section{Spatio-temporal distribution of alder in comparison with all woody vegetation}

Figures 4 (area I), 5 (N part of area II), 6 (S part of area II) and 7 (area III) provide overviews of the changing distribution of channels, bars and vegetation cover for the three areas where $A$. incana was mapped in 2019. Area II is split into two (Figures 5 and 6 ) because it is much larger than areas I and III. We show rectified aerial images from 1986, 1993, 1997, 2003 and 2005 to visualise areas I, II and III before and after the 1990, 1996, 2000 and 2004 floods and also in 2017, the closest image date to the 2019 field survey. In Figure 8 we present the DEM and height distribution of vegetation derived from the 2005 lidar survey (i.e. shortly after the 2004 flood). 

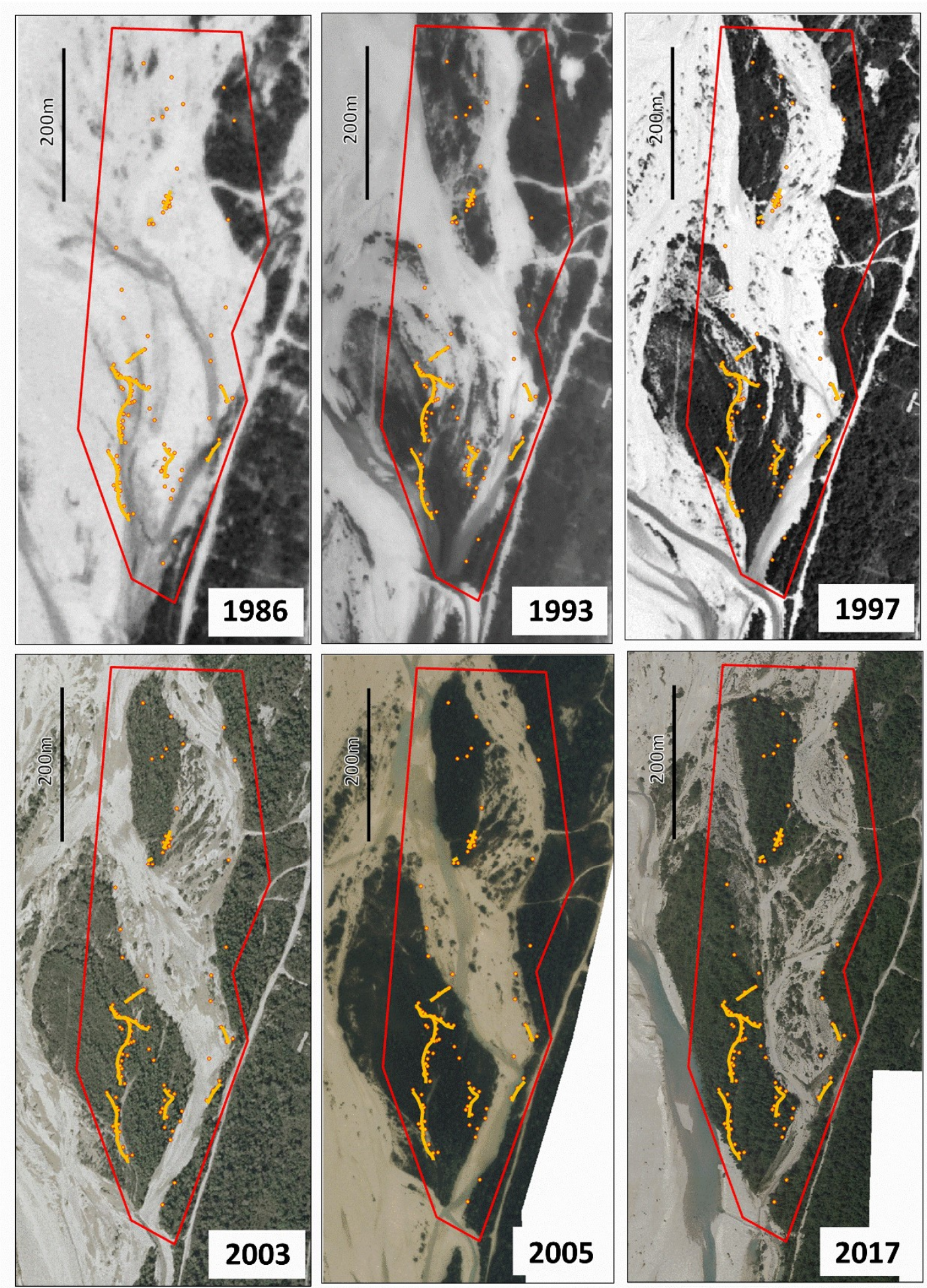

Figure 4: Area I (red polygon) and locations of alder trees surveyed in 2019 (yellow dots) overlain with lines of alder (orange lines) over-plotted on rectified aerial images captured in 1986, 1993, $1997,2003,2005$, and 2017. North is towards the top of the images and flow is from North to South. The 2017 image was obtained from Google Earth: Image (c) 2020 Maxar Technologies. 


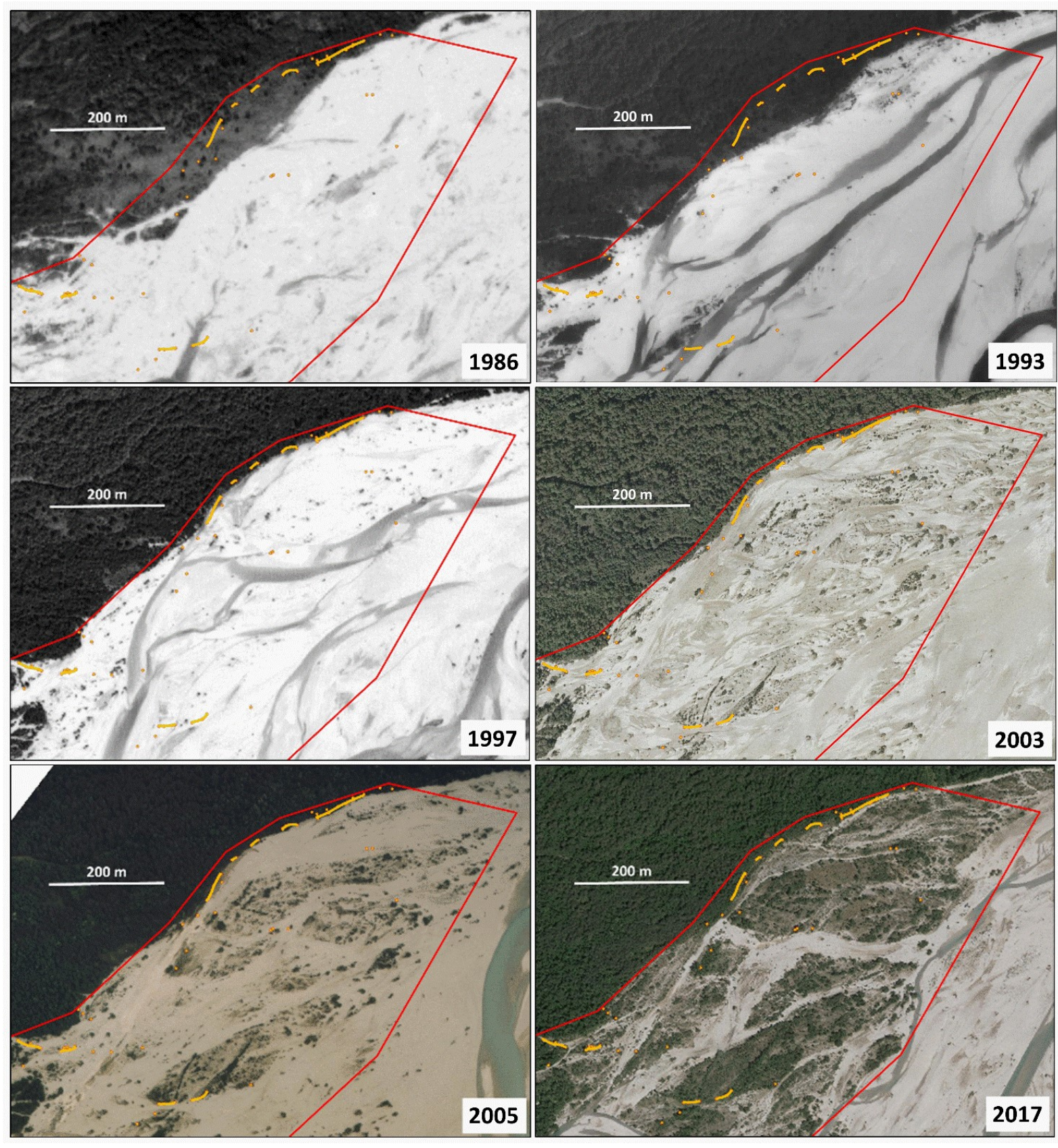

Figure 5: Area IIA (northern part of area II, red polygon) and locations of alder trees surveyed in 2019 (yellow dots) overlain with lines of alder (orange lines) over-plotted on rectified aerial images captured in 1986, 1993, 1997, 2003, 2005, and 2017. North is towards the top of the images and flow is from North East to South West. The 2017 image was obtained from Google Earth: Image (c 2020 Maxar Technologies. 


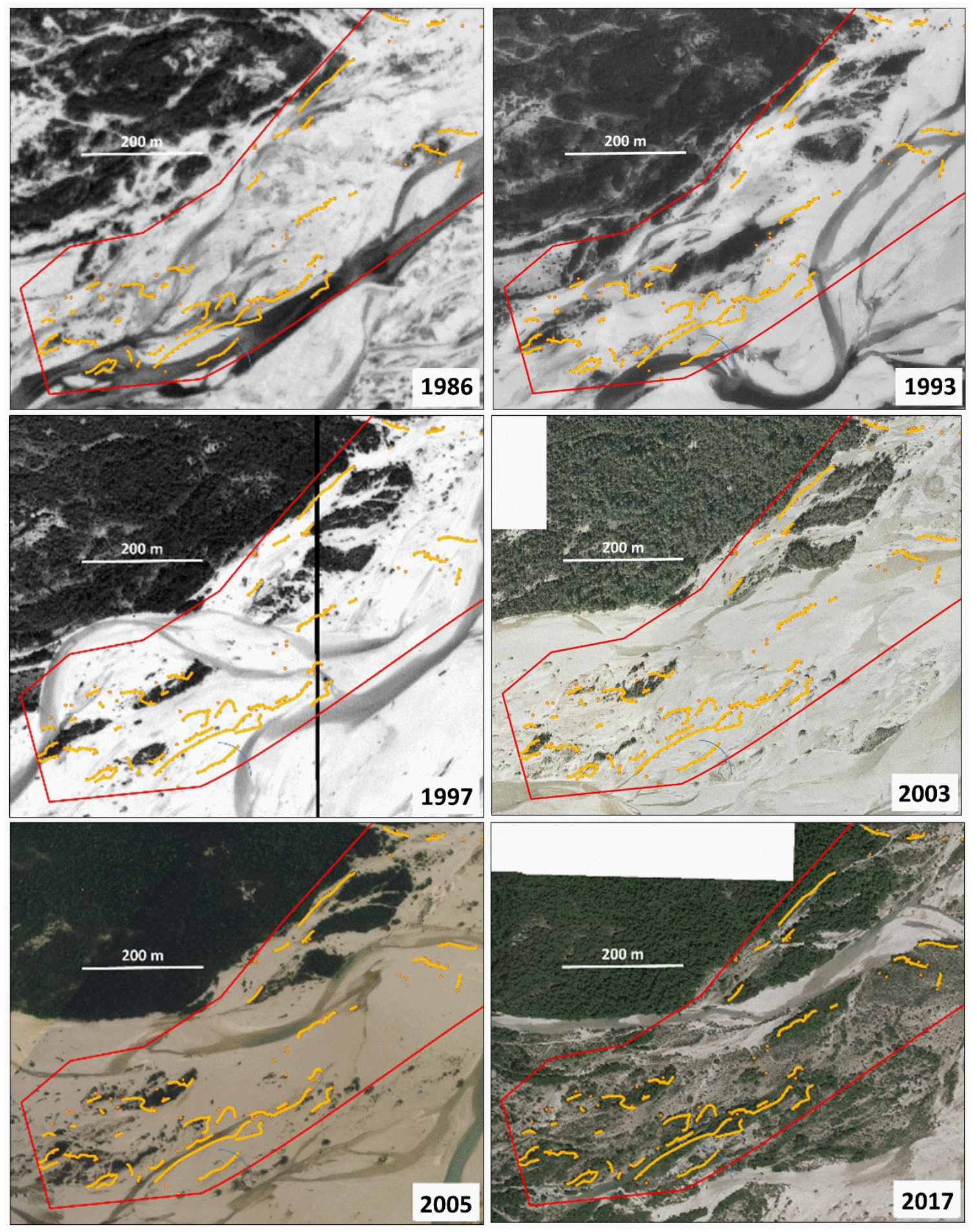

Figure 6: Area IIB (southern part of area II, red polygon) and locations of alder trees surveyed in 2019 (yellow dots) overlain with lines of alder (orange lines) over-plotted on rectified aerial images captured in 1986, 1993,1997, 2003, 2005, and 2017. North is towards the top of the images and flow is from North East to South West. The 2017 image was obtained from Google Earth: Image (c) 2020 Maxar Technologies. 


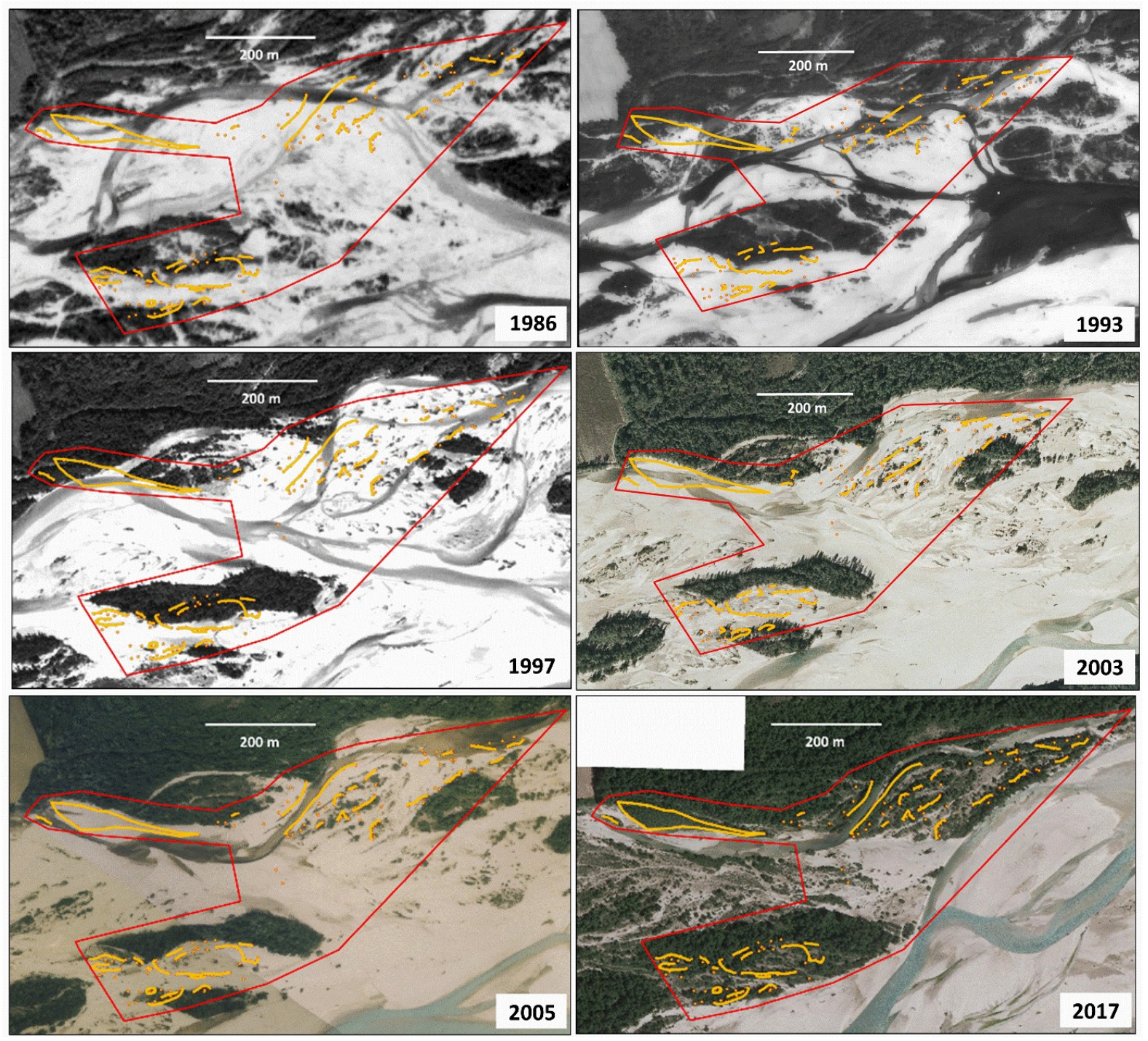

Figure 7: Area III and locations of alder trees surveyed in 2019 (yellow dots) overlain with lines of alder (orange lines) over-plotted on rectified aerial images captured in 1986, 1993, 1997, 2003, 2005, and 2017. North is towards the top of the images and flow is from East to West. The 2017 image was obtained from Google Earth: Image @ 2020 Maxar Technologies. 

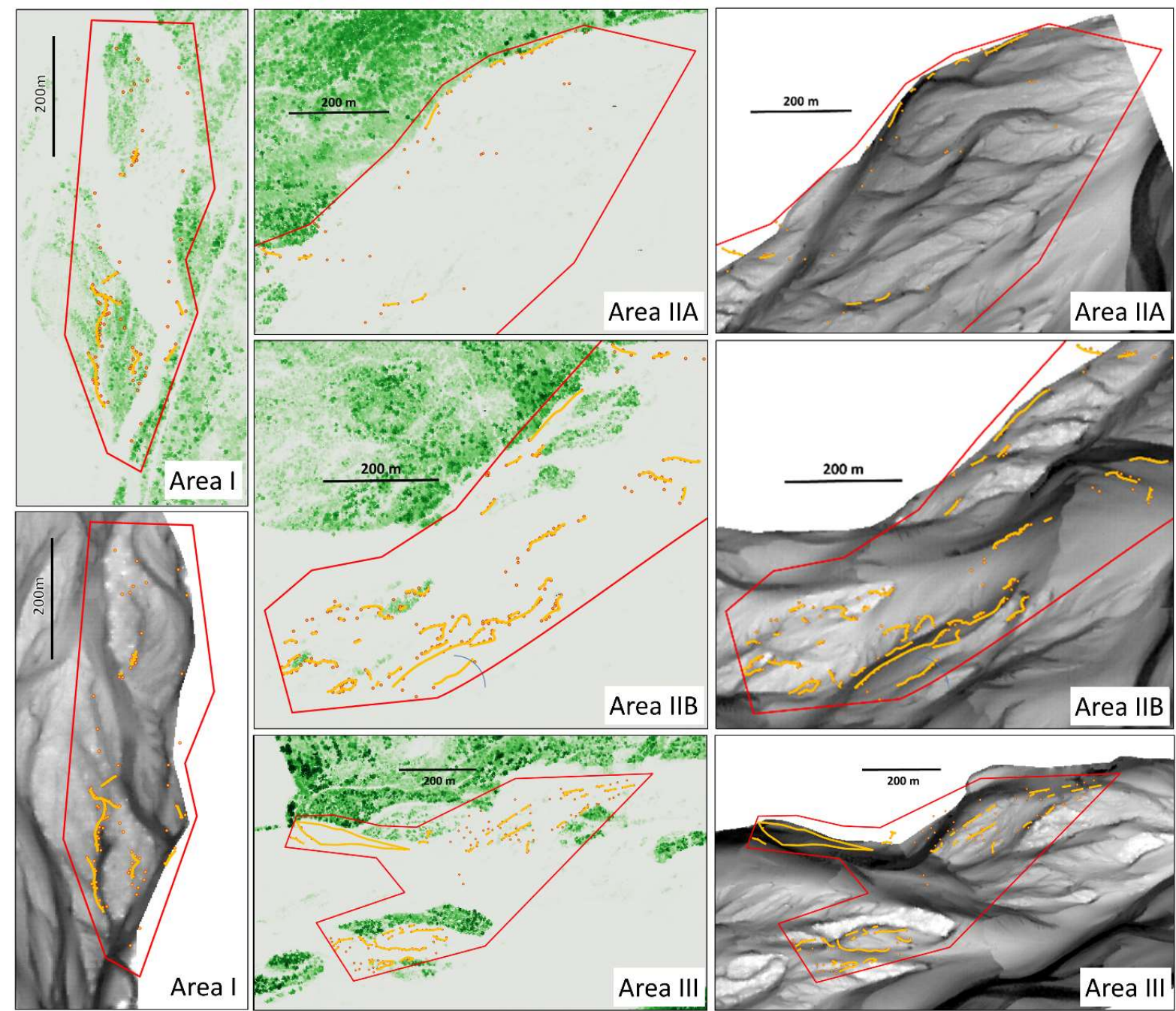

Figure 8: Digital elevation models (grey images - darker greys indicate lower elevations) and vegetation height (green images - darker greens indicate taller vegetation) estimated from the 2005 Lidar survey for areas I, IIA (northern part of II), IIB (southern part of II) and III showing locations of alder trees surveyed in 2019 (yellow dots) overlain with lines of alder (orange lines) over-plotted on rectified aerial images captured in 1986, 1993, 1997, 2003, 2005, and 2017. North is towards the top of the images. 
In area I (Figure 4) the bar and channel layout has changed little since 1986, particularly in the southern half of the area (see also the 2005 DEM, Figure 8). The vegetated area (indicative of the spatial distribution of $P$. nigra) was very small in 1986, but by 1993 patches of trees of varying density had appeared in both the northern and southern parts of area I. Between 1997 and 2003, these vegetated areas matured to form closed canopies, which have largely persisted through 2005 and 2017 , becoming increasingly surrounded by numerous more recently vegetated patches. The 2019 alder locations have mainly been vegetated since before 1993, and in the southern half of the area many are aligned along channel edges that were present in 1986, suggesting that most of the 2019 surveyed alder trees in the southern part have been present since the 1990 flood and may predate it. In the northern part of area I the alders are more scattered. One cluster is located close to the tip of an island that was present in 1997 but may be younger, as the 2005 DEM (Figure 8) confirms that the cluster is aligned along a narrow channel between the island and another vegetated area to the east, which first appears in the 2003 image.

Apart from the mature woodland on the floodplain, the northern part of area II (Area IIA, Figure 5) has displayed a sparse vegetation cover across all of the historical images, although by 2017 this sparse vegetation was enclosed within large coherent patches. Few alder trees were present in 2019. Some isolated trees were located across bars that had been colonised by vegetation, particularly since 2003. Lines of alder are present along a floodplain edge whose position dates back to 1997 and the edges of a few bars that can be seen in the 2003 image and 2005 DEM. In the southern part of area II (Area IIB, Figure 6) several vegetated areas were present in the 1993 image, that have largely persisted as mature closed-canopy patches through all subsequent images. Since 2003 , these mature wooded areas have become increasingly surrounded by sparse and patchy vegetation. Almost all of the alder trees are arranged in lines. Some follow the floodplain edge, which may date back to the edge of an island that is present in the 1986 image. Others correspond to the edges of channels bars and vegetation patches observable in the 2003 image and 2005 DEM. The bed morphology in 2003 and 2005 shows little change and the broad form presumably dates back to the 2000 flood and persists through later images. The remaining alder lines border the edges of areas that have become vegetated since the 2005 image.

In area III (Figure 7) several areas of mature, closed canopy woodland persist from the 1997 image through to 2017, although there are some notable parts of these patches that were removed by erosion between the 1997-2003 and 2005-2017 images, and numerous small vegetated patches have developed since 2005. Virtually all alder trees mapped in 2019 are arranged in lines corresponding to channel and island edges seen in the 2005 DEM (Figure 8) and also present in the 2003 image, suggesting that they date back to the 2000 flood. There is also an area of alder present 
towards the western edge of area III, on a bar that first appears in the 2005 image, suggesting formation during the 2004 flood.

\section{The topographic expression of alder and all woody vegetation}

Figure 9 synthesises information drawn from 2005, 2010 and 2013 lidar surveys on the elevation of the river bed within the entire study reach and the topographic distribution of all woody vegetation cover and locations occupied by alder in 2019 within areas I, II and III. Table 1 lists summary statistics for the bed elevation frequency distributions shown in Figure 9.

There has been little change in the proportional frequency distribution of the riverbed elevation between survey years (Figure 9A) and that for the area under vegetation has changed only slightly (Figure 9B), particularly as vegetation has extended across lower areas of the bed between 2005 and 2010, resulting in decreases in the median, mean and mode of the distributions (Table 1). However, the proportional elevational frequency distribution of the bed at sites where alder $>4 \mathrm{~m}$ tall were observed in 2019 shows notable changes in shape as well as central tendency (Figure 9C). In Figures 9D, E and F, respectively, the alder elevation distributions in 2005, 2010 and 2013 are overlain on the elevation distributions of the entire vegetated area for the same years and the average DEM for the study reach across all dates. Between 2005 and 2013, the elevational distribution of sites where alder was recorded in $\mathbf{2 0 1 9}$ gradually approach but always remains displaced to the left (always at a generally lower elevation) than the distribution of all (i.e. P. nigra-dominated) woody vegetation.

The riverbed elevation frequency distributions extracted from the 2013 lidar data for areas where alder was recorded in 2019 and for all woody vegetation cover are subdivided according to four tree height classes (Figure 10) for areas I, II and III combined (Figure 10A, B, C), and separately for areas I (Figure 10D, E, F), II (Figure 10G, H, I) and III (Figure10J, K, L). Note that for area II, the vegetation data are only for the southern part (Figure 6). The alder and total vegetated area in each bed elevation category are divided according to canopy height, using the ranges that were estimated to correspond to alder growth initiated before the 1996 flood (height $(h)>10 \mathrm{~m}$ ), between 1996 and $2000(8<\mathrm{h}<10 \mathrm{~m})$, between 2000 and $2004(5<\mathrm{h}<8 \mathrm{~m})$ and after the 2004 flood $(\mathrm{h}<5 \mathrm{~m})$. The alder dominance ratios (Figure 10C, F, I, L) are calculated for each elevation class by dividing the alder proportion in each elevation class (Figure 10A, D, G, J) by the total vegetation proportion (Figure $10 B, E, H, K)$. 

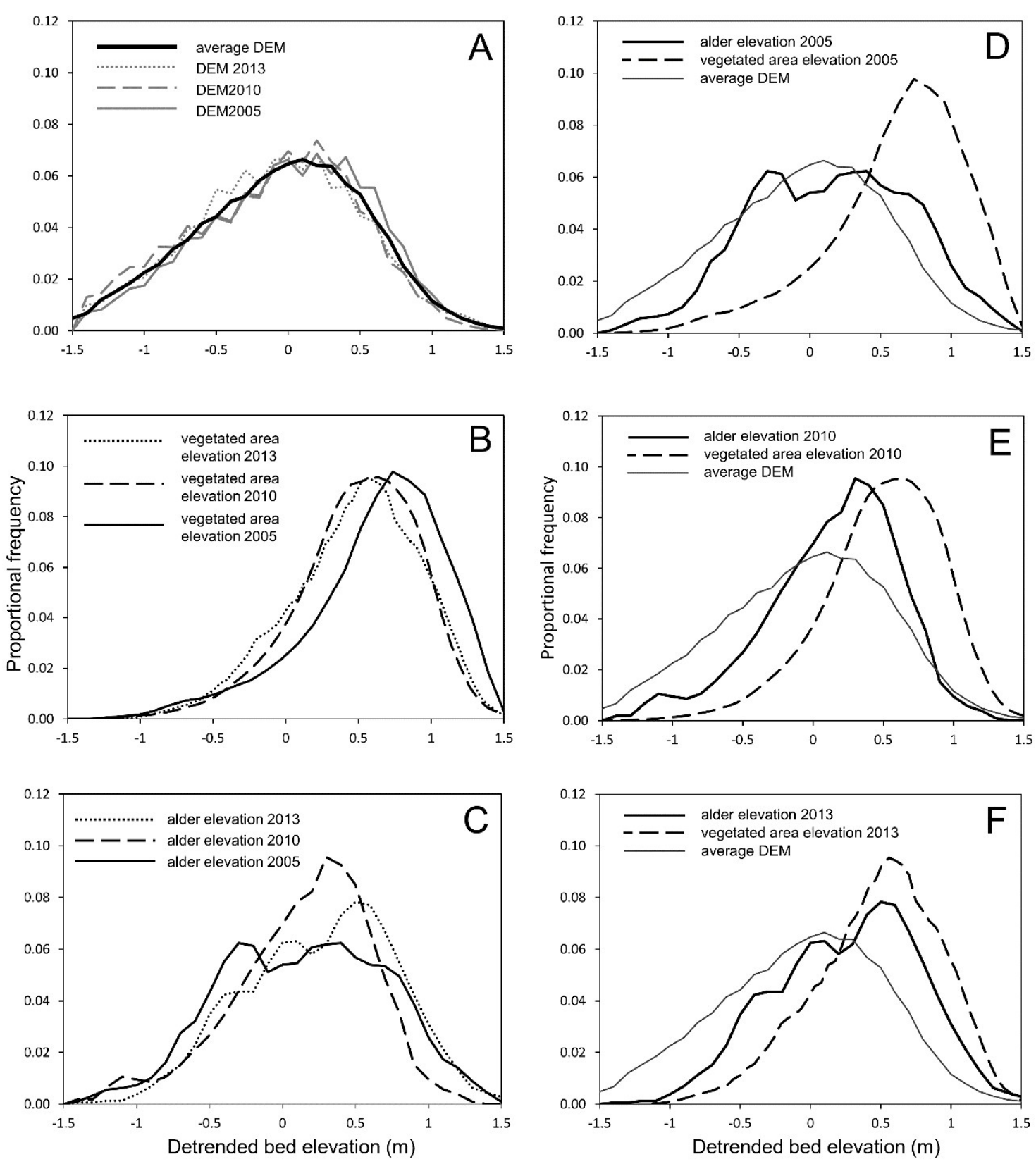

Figure 9: Proportional frequency distributions of (A) the average DEM within areas I, II and III overplotted on the DEMs estimated from lidar data for 2005, 2010, 2013; (b) the elevational distribution of all woody vegetation cover within areas I, II and III from the lidar data for 2005, 2010, 2013; (C) the elevational distribution of the land surface at locations occupied by alder $>4 \mathrm{~m}$ tall in 2019 from the lidar data for 2005, 2010 and 2013. The elevational distribution of all woody vegetation cover and of locations occupied by alder >4 m tall in 2019 in 2005 (D), 2010 (E) and 2013 (F) within areas I, II and III, overplotted on the average DEM for the same areas. 
Table 1 Descriptive statistics extracted from frequency distributions of the elevation of the entire river bed (DEM), of land surface at locations occupied by alder $>4 \mathrm{~m}$ tall in 2019 (alder), and of all woody vegetation cover (vegetated area) estimated from the lidar data for 2005, 2010, 2013 for the whole of within areas I, II and III.

\begin{tabular}{lccccc}
\hline Detrended elevation $(\mathrm{m})$ & Median & Mean & Mode & $\begin{array}{c}\text { Upper } \\
\text { Quartile }\end{array}$ & $\begin{array}{c}\text { Lower } \\
\text { Quartile }\end{array}$ \\
\hline DEM 2005 & 0 & 0.0 & 0.2 & 0.4 & -0.4 \\
DEM 2010 & 0 & -0.1 & 0.2 & 0.4 & -0.5 \\
DEM 2013 & 0 & -0.1 & 0.2 & 0.3 & -0.5 \\
alder 2005 & 0.2 & 0.2 & $-0.3,0.3 *$ & 0.6 & -0.3 \\
alder 2010 & 0.2 & 0.1 & 0.3 & 0.5 & -0.1 \\
alder 2013 & 0.3 & 0.3 & 0.5 & 0.6 & -0.1 \\
vegetated area 2005 & 0.8 & 0.6 & 0.8 & 1 & -0.6 \\
vegetated area 2010 & 0.6 & 0.5 & 0.7 & 0.8 & -0.3 \\
vegetated area 2013 & 0.6 & 0.5 & 0.6 & 0.9 & -0.4 \\
\hline
\end{tabular}

* this frequency distribution has two modes of equal proportional frequency

Unsurprisingly, given that the 2019 alder survey focussed entirely on mature alder individuals (>4 m tall), the bars in the proportional elevational frequency distributions for all woody vegetation cover, show larger proportions of short canopies $(<5 \mathrm{~m})$, but they illustrate where the tallest vegetation is located. The alder are generally taller in area I than in area III, which are taller than in area II. The most frequent height class in area I is $>10 \mathrm{~m}$ and virtually all alder trees are $>8 \mathrm{~m}$. The majority are $>8 \mathrm{~m}$ in area III, whereas alder in area II are mainly $<8 \mathrm{~m}$. Furthermore, the proportional frequency of tall alders $(>8 \mathrm{~m}$ ) relative to shorter ones increases with bed elevation in all areas (i.e. alders are relatively older at higher elevations). Over the total area surveyed (Figure 10C) the relative presence of alder increases below a bed elevation of $+0.2 \mathrm{~m}$, whereas in areas I, II and III it increases at bed elevations below $+0.3 \mathrm{~m},+0.1 \mathrm{~m}$ and $-0.3 \mathrm{~m}$, respectively. In area II there is an increase in the relative presence of alder at the highest elevations (along the floodplain edge) but the proportional frequencies from which the ratio is derived are extremely low. 

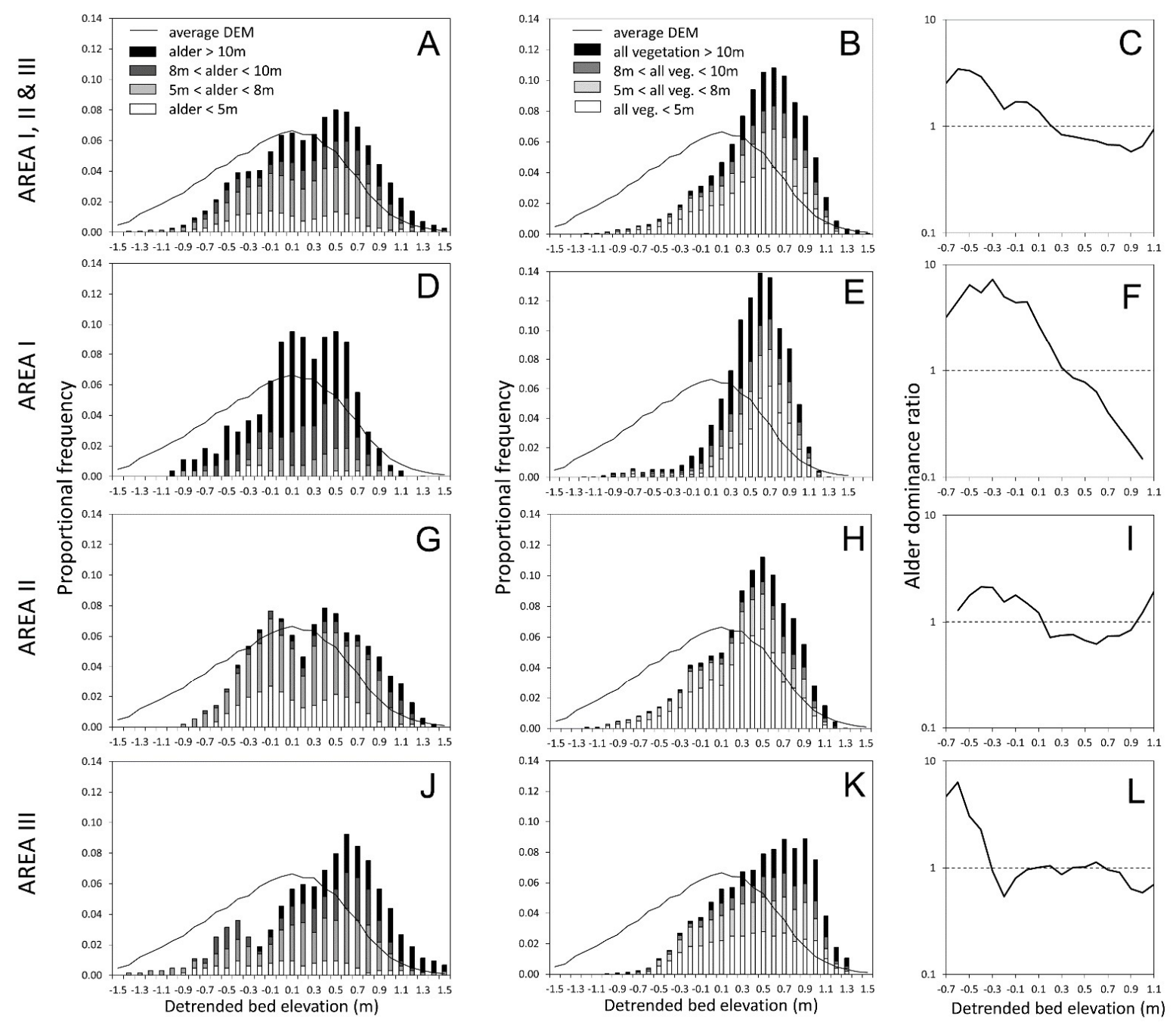

Figure 10: Proportional elevational frequency distribution of alder (A, D, G, J) and the total vegetation cover $(B, E, H, K)$, subdivided into vegetation height classes $(h<5 m, 5<h<8 m, 8<h<10 m$, $h>10 \mathrm{~m}$ ) extracted from the 2013 DEM and overplotted on the average DEM for the entire reach. The alder dominance ratio of the vegetation (see text for explanation) within the bed elevation range -0.7 to $+1.1 \mathrm{~m}$. Data are presented for areas I, II and III combined $(A, B, C)$ and separately for areas I (D, E, F), II (G, H, I), and III (J, K, L). 


\section{DISCUSSION}

We discuss the results of the research in the light of the three aims stated in the introduction.

\section{Research Aim 1: To establish the changing spatial distribution of (P. nigra dominated) woody vegetation in general and $A$. incana alone}

An analysis of changes/persistence of channels, bars and vegetated areas depicted in historical images and lidar data (Figures 4 to 8 ) in relation to the occurrence of four bankfull floods (1990, $1996,2000,2004)$ suggests two main phases in the development of the current, $P$. nigra dominated, woody vegetation cover across areas I, II and III. The precise magnitude of the 1990 and 1996 flood peaks are unknown, but historical aerial images show notable changes in braid plain morphology between the 1986, 1993 and 1997 images (Figures 4 to 7). Thus, the broad morphology of the river bed (major bar and channel pattern) first took on its contemporary form in the 1997 images (1986 in parts of area I). In all three areas (I, II, III), some distinct parts of the river bed and floodplain edges support persistent, mature, closed-canopy vegetation from this period until the most recent (2017) images, suggesting they were colonised following the 1990 and 1996 floods, although their margins have been substantially modified by more recent floods and post-flood recovery. The second phase commences with the 2000 flood, the largest in the time period covered by the historical images (Figure 3), which transformed the distribution of channels and bars in areas between established islands, and removed or modified floodplain and established island edges across the study area (compare 1997 and 2003 images, Figures 4 to 7). The 2004 flood was smaller and induced little change in the distribution of major bars, channels and islands (compare 2003 and 2005 images, Figures 4 to 7) but caused local scour, fill and migration of some features. Since these floods, vegetation has colonised extensive, previously-unvegetated areas, commencing with the appearance of isolated vegetated patches that, by 2017 were often incorporated into large coherent areas enclosing patchy (mixed age) vegetation.

The main feature of the spatial distribution of the alder trees that were mapped in 2019 is that they are highly localised within the vegetated areas and are almost entirely arranged in distinct linear patterns that correspond to the edges of channels, bars, islands and floodplain. The first appearance of vegetation at the alder locations on the available images, suggests that most of these alder lines probably date back to the $\mathbf{2 0 0 0}$ or 2004 floods. However, some are located along floodplain and island edges that date back to the 1996 flood. Distributions of alder-dominated canopy height in 2013 (Figure 10) translated into age by assuming an average annual growth increment of $0.6 \mathrm{~m}$, 
confirm these estimates of the dates of the flood events that are likely to have initiated each of the lines of alder trees. The oldest (tallest) alder trees are mainly in area I, located predominantly along floodplain and island edges and old channel margins cutting across long-established islands. In area III, the margins of long-established islands and floodplain edges were extensively modified by the 2000 flood, so there are fewer older ( $>8 \mathrm{~m}$ ) alder trees than in area I. Area II supports a small proportion of older ( $>8 \mathrm{~m}$ ) trees, mainly confined to remnant floodplain edges dating back to at least 1996. In other parts of the surveyed areas, bed morphology was heavily modified by the 2000 flood, and so many alders in area III and a sizeable proportion in area II are $<8 \mathrm{~m}$ tall, indicating establishment since 2000. One patch of alder in area III covers a bar established during the 2004 flood (Figure 7, 2005 image) and so post-dates that event. These observations support our initial impressions of an expansion in alder within the study reach. However, expansion appears to mainly reflect recovery of the species following the largest flood on record in 2000, which removed many of the edges of features that alder appears to preferentially colonise, rather than any longer term trend towards colonisation of the study reach.

These differences in spatio-temporal patterns of the vegetated area in general and the alder trees mapped in 2019 may be explained by a number of factors that influence the recruitment of $A$. incana and $P$. nigra. First, although $A$. incana can establish from stumps and root suckers, these tend to be associated with older trees (Rytter, 1996) of ages rarely achieved by vegetated surfaces on the study reach (Zanoni et al., 2008). Therefore, colonisation of the river bed by this species is most likely to be initiated from seeds. Furthermore, because the species appears to produce a short-term persistent seed bank (Thompson et al., 1997, Gosling, 2007), recruitment from seeds is not heavily dependent upon flood timing, but does require dispersal by floods to suitable germination sites, since wind only disperses the seeds short distances. In contrast, the seeds of $P$. nigra have an extremely short period of viability following their release in spring, and although they are widely dispersed by wind, the likelihood of arriving at a suitable moist, unvegetated germination site is much higher following water dispersal. Since the four large floods that were investigated occurred in the autumn (November 1990, June-November 1996, November 2000, October 2004), flood dispersal of seeds is unlikely to have led to significant recruitment of $P$. nigra, but is very likely to have supported recruitment of $A$. incana.

Second, vegetative reproduction provides an alternative recruitment pathway for both species that is relatively insensitive to the timing of flood dispersal. However, lack of disturbance and moisture availability following propagule deposition remain influential, with their importance declining the larger the vegetative fragment (Francis, 2007). Large uprooted trees have significant internal resources and are relatively resistant to modest flood disturbances, often benefiting from such 
disturbances by retaining fine sediments that may promote shoot and root growth (Gurnell et al., 2005). Populus. nigra regenerates from many different types and sizes of vegetative fragments (twigs to whole uprooted trees) but regeneration of $A$. incana is more limited and, because trees rarely survive to a sufficient age within the study reach, is probably confined to sprouting from stumps. Stump sprouts are undoubtedly an important means of survival for established alder trees that are damaged but not uprooted by floods. Sprouts may also develop from flood uprooted and deposited trees, although this is less likely given $A$. incana's preference for moist, nutrient rich sites (Rytter, 1996) that are rarely available to uprooted trees deposited on the open, free-draining gravel bars of the Tagliamento braid plain. Moist but usually coarse sediments are available along braid channel margins and finer, moisture-retentive sediments with some organic content are associated with pre-existing vegetated landforms (Petts et al., 2000, Gurnell et al., 2008, Mardhiah et al., 2014). Therefore, channel, floodplain, pioneer and established island edges may provide suitable sites for alder to regenerate from uprooted, snagged stumps, and undoubtedly offer suitable sites for germination of alder seeds, explaining the linear patterns displayed by this species.

Third, whether recruitment commences from seeds or vegetative fragments, survival depends on favourable local growing conditions and sufficient time for growth before another major flood disturbance. For most riparian tree species there is a critical balance between being inundated by shallow, gentle floods that may promote growth, and deeper, disturbing floods that may uproot or bury plants. Sizeable flood disturbances occur frequently on the Tagliamento (Figure 3 ) and so mature trees are largely confined to high bar surfaces where disturbances are at a minimum and 'windows of opportunity' (Balke et al., 2014) for growth and establishment are at a maximum. Based on field observations, riparian tree seedlings on the Tagliamento require a window of opportunity of at least two growing seasons to resist uprooting by modest flood disturbances, and four years is probably needed for trees to have a chance of surviving to maturity. On high bar surfaces, such four year windows appear to follow the 1996 and 2000/2004 floods (Figure 3).

\section{Research Aim 2: To investigate whether river bed topography can be associated with the changing spatial distribution of all woody vegetation and of $A$. incana, alone}

Evidence to support associations between vegetation and bed topography were presented in Figures 9 and 10. This evidence only spans a period of eight years with some distinct hydrological properties (Figure 3). There were no significant floods between 2005 and 2008. In October 2008 there was a brief bankfull event, followed by four years of numerous intermediate flow pulses (Tockner et al., 2000) culminating in a large flood in November 2012. 
In 2005, sizeable trees had survived within established patches from the first phase of vegetation development. However, the four year window of opportunity between the 2004 and 2008 flood events probably also allowed newly recruited trees within the second phase of vegetation development to develop anchoring root systems and above-ground biomass that could trap fluvial sediments during flow pulses and aggrade bar surfaces, so lowering their risk of flood inundation (Gurnell, 2016). Aggradation around vegetation of $0.5 \mathrm{~m}$ in the first five years of growth and 1.5 to 2 m over 25 years have been observed in the study reach (Gurnell et al., 2019). Hortobagyi et al. (2018, following Eichel et al., 2015) have described such periods of landform building as 'biogeomorphic feedback windows', providing trees with elevational protection from floods and finer, moisture-retentive sediments within which to develop extensive root systems (Holloway et al., 2017a, b, c). Furthermore, the numerous flow pulses between the 2008 and 2012 floods likely provided opportunities for further sediment trapping as the surviving trees matured, providing an increasing potential for them to survive the 2012 event.

Between 2005 and 2013, there was little overall change in bed topography (Figure 9A) but the parts of the bed covered by woody vegetation expanded from the highest parts of the bed (vegetated areas surviving from the first phase of vegetation development following the 1990 and 1996 floods) across surrounding lower areas (the second phase of vegetation development following the 2000 flood) (Figure 9B). Such rapid expansion of vegetated areas between floods reflects the occurrence of a four year window of opportunity and is typical of the middle reaches of the Tagliamento (Bertoldi et al., 2011a). It is impossible to firmly separate cause and effect from these aggregated graphs. However, the difference in the modes of the elevation frequency distributions for the vegetated area may highlight aggradation around the areas of vegetation from the first phase of vegetation development (2005 elevation distribution) and its combination with more restricted aggradation around the younger second phase vegetation (2010, 2013 elevation distributions), remembering that graphs from all dates incorporate the surviving first phase vegetated areas. However, likely interactions between areas colonised by alder and the underlying river bed (Figure 9C) are clearer, not least because many of the 2019 alder trees post-date the 2000 flood. The elevation of the bed at sites occupied by alder individuals taller than $4 \mathrm{~m}$ (> 7 years old) in 2019 generally increases from 2005 to 2013 (Figure 9C). The elevation frequency distribution of the area occupied by alder trees also progressively approaches that of woody vegetation in general (compare Figures 9D, E, F) over eight years, while still maintaining a significant presence across relatively lower areas of the river bed. These patterns suggest aggradation of the bed around alder trees and also recruitment of alder at lower elevations. Overall, alder appears to be colonising and aggrading the lower edges of the area occupied by woody vegetation over this eight year period. The link between 
topography and age of vegetation in general and alder in particular is illustrated using the 2013 lidar data set (Figure 10), confirming the predominant presence of the tallest trees (Figure 10B, E, H, K) and the tallest (oldest) alder trees (Figure 10A, D, G, J) within the most elevated areas of the river bed, with younger alder trees most notable in the lower areas.

\section{Research Aim 3: To consider whether $\boldsymbol{A}$. incana displays any particular characteristics in its spatial and topographic distribution that may indicate that it is complementing the physical engineering role of $P$. nigra}

Virtually all of the alder trees surveyed in 2019 were distributed in lines. Lines or wider strips are typical of the spatial distribution of cohorts of the Salicaceae along many rivers, reflecting the timing (spring) and flood characteristics needed for their recruitment (e.g. Johnson, 2000; Braatne et al., 2007, Rood et al., 2003, 2005, 2008; Mouw et al., 2013), and also noted for $A$. incana seeds dispersed by relatively smaller autumn floods (Mouw et al., 2013). However, the lines observed for alder on the Tagliamento are very narrow, frequently being a single tree or at most two to three trees wide and corresponding to floodplain, island or channel edges. This suggests that, although flood timing is less important for recruitment of $A$. incana than $P$. nigra within the study area, topographic position, shelter and substrate may be more important for supporting early development. It may also indicate that the edges of vegetated areas (pioneer and building islands, Gurnell et al., 2001, 2005) initiated by sprouting of large $P$. nigra propagules, may provide particularly suitable sites for $A$. incana recruitment, and that in such circumstances $A$. incana may be a secondary coloniser following quickly after and benefitting from initial colonisation by P. nigra. Indeed, only one broader area of predominantly alder was identified in our field survey. This was located on a bar deposited during the 2004 flood (Area III, Figures 7 and 8), but even here, the bar was sheltered in the lee of an island. This area of alder is similar to elongated vegetated patches created by Salicaceae recruitment from seeds (e.g. Rood et al., 2003, 2005), but its sheltered location and finer substrate echoes the site characteristics associated with the lines of alder.

The spatially aggregated data for woody vegetation in general within areas I, II and III, disguises the detail of interactions with the underlying river bed. Nevertheless, previous research at finer spatial scales within the study reach (Gurnell et al., 2019) and from comparisons of $1 \mathrm{~km}$ segments of a 20 $\mathrm{km}$ length of the river containing the study reach (Bertoldi et al., 2011b) have already clearly established a topographic signature of $P$. nigra-dominated landform development across time and space. However, no such previous analysis exists for A. incana. Regardless of the age or spatial pattern of the alder trees, the present analysis has demonstrated that they are associated with 
particular elevations across the braid plain (Figures 9 and 10). The species is predominantly located at lower elevations than the vegetated area in general, rendering it more susceptible to removal by large floods (such as the 2000 flood) than P. nigra, which occupies a wider elevation range. During the window of opportunity tracked by the lidar data between 2005 and 2013, the sites occupied in 2019 by alder trees increased their elevation to approach that for the entire vegetated area. This temporal increase in bed elevation coupled with the fact that alder trees predominantly occur in lines along the edges of features, suggests that $A$. incana is not only a secondary coloniser but that it is also associated with pronounced aggradation around the edges of vegetated areas giving it a notable complementary role to $P$. nigra in engineering the river bed of the study reach.

\section{SUMMARY AND CONCLUSIONS}

Although our initial interest in $A$. incana was stimulated by an apparent expansion in its cover in the study reach during the last two decades, this does not seem to be attributable to an expansion of the local range of the species. Rather, it is probably attributable to enormous reworking of the reach morphology during the largest flood on record (in 2000). The fact that $A$. incana is generally observed in lines at relatively lower elevations and along the edges of vegetated areas, make the species more susceptible to damage and removal by such a large flood.

The observed lines of alder correspond to floodplain, island, bar and channel edges, which may provide the moisture, protection and finer sediments that $A$. incana propagules require to germinate or sprout and establish. The nature of the propagules from which the surveyed trees developed are unknown but adjacent alder trees are often of very similar height and simple canopy structure, suggesting that they have grown from seeds deposited at the same time. Nevertheless, the sheltered, rough character of floodplain, island, bar and channel edges could also offer sites where uprooted trees could snag, providing opportunities for regeneration from stump sprouts. This may explain the more irregular multi-trunk form and wider spacing of some of the surveyed trees, although flood damage could also explain their complex canopy structure.

Given their association with floodplain and island edges and the relationship of taller (older) trees with more elevated surfaces, $A$. incana in the study reach appears to complement the physical engineering of the dominant species, $P$. nigra. This suggests that $P$. nigra may facilitate colonisation by alder but then both species trap sediments to aggrade channel edges and bar surfaces and build island and floodplain landforms. Certainly over the studied period, the spatial distribution of $A$. 
incana, regardless of its age, has preserved its origins along landform edges, and it appears to have helped to aggrade and root-reinforce the edges of island features initiated mainly by $P$. nigra.

Such an interaction between species may occur on other rivers and is described among Salicaceae species by Hortobagyi et al. (2018). Here we have found evidence of complementary physical engineering between two species from different families and the processes of colonisation, facilitation and landform engineering seem to reflect distinct differences in species traits. Although we have demonstrated specific processes and interactions between two riparian tree species drawn from different families at a broad scale within the study reach, many questions remain unanswered. At a finer scale, we are exploring these complementary interactions between $A$. incana and $P$. nigra to establish their specific geomorphic outcomes in different river bed settings. The observed relationships in physical engineering of the river bed by these two species needs to be confirmed at other sites. Additionally, it is likely that similar roles may be performed by other combinations of species in other biogeographical settings, but this also remains to be investigated.

\section{ACKNOWLEDGMENTS}

The authors thank Patrice Carbonneau and an anonymous referee for their extremely helpful and constructive criticisms of the submitted manuscript, which have undoubtedly helped us to present our research far more clearly. However, any shortcomings in the presentation and analysis underpinning this paper remain the full responsibility of the authors. The authors also acknowledge the UK Natural Environment Research Council for providing the 2005 lidar data and images; Nicola Surian, University of Padova (CARIPARO project) for the 2010 lidar data and images, Yasuhiro Takemon, University of Kyoto for the 2013 lidar data and images, the 'Autorità di Bacino Distrettuale delle Alpi Orientali' and the 'Direzione Regionale della Pianificazione Territoriale, Regione Autonoma Friuli-Venezia Giulia' for the provision of 1986, 1993, 1997 and 2003 images. Figures 4, 5, 6 and 7 include extracts of an image captured on 26 June 2017 from Google Earth, and from the following supplier: Maxar Technologies. In using extracts from this image, we have conformed to guidelines available from https://www.google.com/permissions/geoguidelines/attr-guide.html (accessed 27 February 2020) including image attributions in the Figure caption that conform to 'the text of your attribution must say the name "Google" and the relevant data provider(s), such as "Map data: Google, DigitalGlobe"' and we have not obtained written permission to use these images because the guidelines state that 'Due to limited resources and high demand, we're unable to sign any letter or contract specifying that your project or use has our explicit permission'. The data that support 
the findings of this study are available from the corresponding author upon reasonable request.

\section{REFERENCES}

Aosaar, J., Uri, V., 2008. Biomass production of grey alder, hybrid alder and silver birch stands on abandoned agricultural land, Forestry Studies, 48: 53-56.

Balke, T., Herman, P.M.J., Bouma, T.J., 2014. Critical transitions in disturbance-driven ecosystems : identifying Windows of Opportunity for recovery. Journal of Ecology, 102: 700-708.

Bankhead, N.L., Thomas, R.E., Simon, A., 2017. A combined field, laboratory and numerical study of the forces applied to, and the potential for removal of, bar top vegetation in a braided river. Earth Surface Processes and Landforms, 42(3): 439-459.

Barsoum, N., 2001. Relative contributions of sexual and asexual regeneration strategies in Populus nigra and Salix alba during the first years of establishment on a braided gravel bed river. Evolutionary Ecology, 15(4-6): 255-279.

Bertoldi, W., Drake, N.A., Gurnell, A.M., 2011a. Interactions between river flows and colonizing vegetation on a braided river: exploring spatial and temporal dynamics in riparian vegetation cover using satellite data. Earth Surface Processes and Landforms, 36(11): 1474-1486.

Bertoldi, W., Gurnell, A.M., Drake, N.A., 2011b. The topographic signature of vegetation development along a braided river: Results of a combined analysis of airborne lidar, color air photographs, and ground measurements. Water Resources Research, 47: W06525.

Bertoldi, W., Gurnell, A.M., Surian, N., Tockner, K., Zanoni, L., Ziliani, L., Zolezzi, G., 2009.

Understanding reference processes: linkages between river flows, sediment dynamics and vegetated landforms along the Tagliamento River, Italy. River Research and Applications 25: 501-516.

Bornette, G., Tabacchi, E., Hupp, C., Puijalon, S., Rostan, J.C., 2008. A model of plant strategies in fluvial hydrosystems. Freshwater Biology, 53(8): 1692-1705.

Braatne, J.H., Jamieson, R., Gill, K.M. and Rood, S.B., 2007. Instream flows and the decline of riparian cottonwoods along the Yakima River, Washington, USA. River Research and Applications, 23: 247267.

Bywater-Reyes, S., Wilcox, A.C., Diehl, R.M., 2017. Multiscale influence of woody riparian vegetation on fluvial topography quantified with ground-based and airborne lidar. Journal of Geophysical Research: Earth Surface, 122(6): 1218-1235. 
Camporeale, C., Ridolfi, L., 2006. Riparian vegetation distribution induced by river flow variability: A stochastic approach. Water Resources Research, 42: W10415.

Chapin, F.S., Conway, A.J., Johnstone, J.F., Hollingsworth, T.N., Hollingsworth, J., 2016. Absence of net long-term successional facilitation by alder in a boreal Alaska floodplain. Ecology, 97(11): 29862997.

Chiatante, D., Beltotto, M., Onelli, E., Di lorio, A., Montagnoli, A., Scippa, S.G., 2010. New branch roots produced by vascular cambium derivatives in woody parental roots of Populus nigra L. Plant Biosystems, 144(2): 420-433.

Corenblit, D., Steiger, J., Gurnell, A.M., Naiman, R.J., 2009. Plants intertwine fluvial landform dynamics with ecological succession and natural selection: a niche construction perspective for riparian systems. Global Ecology and Biogeography, 18(4): 507-520.

Corenblit, D., Tabacchi, E., Steiger, J., Gurnell, A.M., 2007. Reciprocal interactions and adjustments between fluvial landforms and vegetation dynamics in river corridors: A review of complementary approaches. Earth-Science Reviews, 84(1-2): 56-86.

de Rigo, D., Enescu, C.M., Houston Durrant, T., Caudullo, G., 2016. Populus nigra in Europe: distribution, habitat, usage and threats. In: J. San-Miguel-Ayanz, D. de Rigo, G. Caudullo, T. Houston Durrant and A. Mauri (Editors), European Atlas of Forest Tree Species. Publ. Off. EU, Luxembourg, pp. 136-137.

Eichel, J., Corenblit, D., Dikau, R., 2015. Conditions for feedbacks between geomorphic and vegetation dynamics on lateral moraine slopes: a biogeomorphic feedback window. Earth Surface Processes and Landforms, 41: 406-419.

Francis, R.A., 2007. Size and position matter: riparian plant establishment from fluvially deposited trees. Earth Surface Processes and Landforms, 32(8): 1239-1243.

Francis, R.A., Corenblit, D., Edwards, P.J., 2009. Perspectives on biogeomorphology, ecosystem engineering and self-organisation in island-braided fluvial ecosystems. Aquatic Sciences, 71: 290304.

Francis, R., Gurnell, A.M., 2006. Initial establishment of vegetative fragments within the active zone of a braided gravel-bed river (River Tagliamento, NE Italy). Wetlands Ecology and Management, 26(3): 641-648.

Gosling, P., 2007. Raising trees and shrubs from seed, Edinburgh. Forestry Commission Practice Guide, Forestry Commission, 231 Corstorphine Road, Edinburgh EH12 7AT, Umited Kingdom, 28p. 
Gregory, S.V., Swanson, F.J., McKee, W.A., Cummins, K.W., 1991. An Ecosystem Perspective of Riparian Zones. BioScience, 41(8): 540-551.

Guilloy-Froget, H., Gonzalez, E., Muller, E., Hughes, F.M.R., Barsoum, N., 2011. Abrupt Drops in Water Table Level Influence the Development of Populus nigra and Salix alba Seedlings of Different Ages. Wetlands, 31(6): 1249-1261.

Guilloy-Froget, H., Muller, E., Barsoum, N., Hughes, F.M.R., 2002. Dispersal, germination, and survival of Populus nigra L. (Salicaceae) in changing hydrologic conditions. Wetlands, 22(3): 478-488. Gurnell, A.M., 2014. Plants as river ecosystem engineers. Earth Surface Processes and Landforms, 39 : 4-25.

Gurnell, A.M., 2016. Trees, wood and river morphodynamics: results from 15 years research on the Tagliamento River, Italy. In: D. Gilvear, Greenwood, M., Thoms, M., Wood, P. (Editor), River Systems: Research and Management for the 21st Century. Wiley, pp. 132-155.

Gurnell, A.M., Bertoldi, W., Corenblit, D., 2012. Changing river channels: the roles of hydrological processes, plants and pioneer landforms in humid temperate, mixed load, gravel bed rivers. Earth Science Reviews, 111: 129-141.

Gurnell, A.M., Bertoldi, W., Francis, R.A., Gurnell, J., Mardhiah, U., 2019. Understanding processes of island development on an island braided river over timescales from days to decades. Earth Surface Processes and Landforms, 44(2): 624-640.

Gurnell, A.M., Blackall, T.D. and Petts, G.E., 2008. Characteristics of freshly deposited sand and finer sediments along an island-braided, gravel-bed river: The roles of water, wind and trees.

Geomorphology, 99: 254-269.

Gurnell, A.M., Corenblit, D., García de Jalón, D., González del Tánago, M., Grabowski, R.C., O'Hare, M.T., Szewczyk, M., 2016. A conceptual model of vegetation-hydrogeomorphology Interactions within river corridors. River Research and Applications, 32(2): 142-163.

Gurnell, A.M., Petts, G.E., 2002. Island-dominated landscapes of large floodplain rivers, a European perspective. Freshwater Biology, 47: 581-600.

Gurnell, A.M., Petts, G.E., 2006. Trees as riparian engineers: the Tagliamento River, Italy. Earth Surface Processes and Landforms, 31: 1558-1574.

Gurnell, A.M., Petts, G.E., 2011. Hydrology and Ecology of River Systems. In: P. Wildere (Editor), Treatise on Water Science. Academic Press, Oxford, pp. 237-269. 
Gurnell, A.M., Petts, G.E., Hannah, D.M., Smith, B.P.G., Edwards, P.J., Kollmann, J., Ward, J.V., Tockner, K., 2001. Riparian vegetation and island formation along the gravel-bed Fiume Tagliamento, Italy. Earth Surface Processes and Landforms, 26(1): 31-62.

Gurnell, A., Tockner, K., Edwards, P.J., Petts, G.E., 2005. Effects of deposited wood on biocomplexity of river corridors. Frontiers in Ecology and Environment, 3(7): 377-382.

Holloway, J.V., Rillig, M.C., Gurnell, A.M., 2017a. Underground Riparian Wood: Buried Stem and Coarse Root Structures of Black Poplar (Populus nigra L.). Geomorphology, 279: 188-198.

Holloway, J.V., Rillig, M.C., Gurnell, A.M., 2017b. Underground Riparian Wood: Reconstructing the processes influencing buried stem and coarse root structures of Black Poplar (Populus nigra L.). Geomorphology, 279: 199-208.

Holloway, J.V., Rillig, M.C., Gurnell, A.M., 2017. Physical environmental controls on riparian root profiles associated with black poplar (Populus nigra L.) along the Tagliamento River, Italy. Earth Surface Processes and Landforms, 42: 1262-1273.

Hortobágyi, B., Corenblit, D., Steiger, J., Peiry, J.L., 2018. Niche construction within riparian corridors. Part I: Exploring biogeomorphic feedback windows of three pioneer riparian species (Allier River, France). Geomorphology, 305: 94-111.

Houston Durrant, T., de Rigo, D., Caudullo, G., 2016. Alnus incana in Europe: distribution, habitat, usage and threats. . In: J. San-Miguel-Ayanz, de Rigo, D., Caudullo, G., Houston Durrant, T., Mauri, A. (Editor), European Atlas of Forest Tree Species. Publ. Off. EU Luxembourg, pp. 66-67.

Huss-Danell, K., Lundmark, J.-E., 1988. Growth of nitrogen-fixing Alnus incana and Lupinus spp. for restoration of degenerated forest soil in northern Sweden. Studia Forestalia Suecica, Swedish University of Agricultural Sciences, Faculty of Forestry, Uppsala, Sweden, Report 181, 20pp., ISBN 91576-3516-1

Imada, S., Yamanaka, N. and Tamai, S., 2008. Water table depth affects Populus alba fine root growth and whole plant biomass. Functional Ecology, 22(6): 1018-1026.

Imbert, E., Lefèvre, F., 2003. Dispersal and gene flow of Populus nigra (Salicaceae) along a dynamic river system. Journal of Ecology, 91(3): 447-456.

Johansson, T., 2005. Stem volume equations and basic density for grey alder and common alder in Sweden. Forestry, 78(3): 249-262. 
Johnson, W.C., 2000. Tree recruitment and survival in rivers: influence of hydrological processes. Hydrological Processes, 14(16-17): 3051-3074.

Karrenberg, S., Edwards, P.J., Kollmann, J., 2002. The life history of Salicaceae living in the active zone of floodplains. Freshwater Biology, 47: 733-748.

Karrenberg, S., Kollmann, J., Edwards, P.J., Gurnell, A.M., Petts, G.E., 2003. Patterns in woody vegetation along the active zone of a near-natural Alpine river. Basic and Applied Ecology, 4: 157166.

Karrenberg, S., Suter, M., 2003. Phenotypic trade-offs in the sexual reproduction of Salicaceae from flood plains. American Journal of Botany, 90(5): 749-754.

Kollmann, J., Vieli, M., Edwards, P.J., Tockner, K., Ward, J.V., 1999. Interactions between vegetation development and island formation in the Alpine river Tagliamento. Applied vegetation Science, 2: 25-36.

Kominoski, J.S., Follstad Shah, J.J., Canhoto, C., Fischer, D.G., Giling, D.P., González, E., Griffiths, N.A., Larrañaga, A., LeRoy, C.J., Mineau, M.M., McElarney, R., Shirley, S.M., Swan, C.M., Tiegs, S.D., 2013. Forecasting functional implications of global changes in riparian plant communities. Frontiers in Ecology and Environment, 11(8): 423-432.

Krzaklewski, W., Pietrzykowski, M., Wos, B., 2012. Survival and growth of alders (Alnus glutinosa (L.) Gaertn. and Alnus incana (L.) Moench) on fly ash technosols at different substrate improvement. Ecological Engineering, 49: 35-40.Mahoney, J.M., Rood, S.B., 1998. Streamflow requirements for cottonwood seedling recruitment: an integrative model. . Wetlands, 18: 634-645.

Mahoney, J.M., Rood, S.B., 1998. Streamflow requirements for cottonwood seedling recruitment: an integrative model. Wetlands, 18: 634-645.

Mardhiah, U., Caruso, T., Gurnell, A.M., Rillig, M.C., 2014. Just a matter of time: Fungi and roots significantly and rapidly aggregate soil over four decades along the Tagliamento River, NE Italy. Soil Biology and Biochemistry, 75: 133-142.

Moggridge, H., Gurnell, A.M., 2009. Controls on the sexual and asexual regeneration of Salicaceae along a highly dynamic, braided river system. Aquatic Sciences, 71: 305-317.

Mouw, J.E.B., Chaffin, J.L., Whited, D.C., Hauer, F.R., Matson, P.L. and Stanford, J.A., 2013. Recruitment and successional dynamics diversify the shifting habitat mosaic of an Alaskan floodplain. River Research and Applications, 29(6): 671-685. 
Naiman, R.J., Decamps, H., McClain, M.E., 2005. Riparia: Conservation and Management of Streamside Communities. Elsevier, Burlington, MA, USA.

Pasquale, N., Perona, P., Francis, R., Burlando, P., 2012. Effects of streamflow variability on the vertical root density distribution of willow cutting experiments. Ecological Engineering, 40: 167-172.

Petts, G.E., Gurnell, A.M., Gerrard, A.J., Hannah, D.M., Smith, B.P.G., Edwards, P.J., Kollmann, J., Ward, J.V., Tockner, K., 2000. Longitudinal variations in exposed riverine sediments: a context for the development of vegetated islands along the Fiume Tagliamento, Italy. Aquatic Conservation: Marine and Freshwater Ecosystems, 10: 249-266.

Polvi, L., Wohl, E., 2013. Biotic drivers of stream planform - implications for understanding the past and restoring the future. Bioscience, 63: 439-452.

Polzin, M.L., Rood, S.B., 2006. Effective disturbance: Seedling safe sites and patch recruitment of riparian cottonwoods after a major flood of a mountain river. Wetlands, 26(4): 965-980.

Rood, S.B., Gourley, C.R., Ammon, E.M., Heki, L.G., Klotz, J.R., Morrison, M.L., Mosley, D., Scoppettone, G.G., Swanson, S. and Wagner, P.L., 2003. Flows for Floodplain Forests: A Successful Riparian Restoration. BioScience, 53(7): 647-656.

Rood, S.B., Pan, J., Gill, K.M., Franks, C.G., Samuelson, G.M. and Shepherd, A., 2008. Declining summer flows of Rocky Mountain rivers: Changing seasonal hydrology and probable impacts on floodplain forests. Journal of Hydrology, 349(3-4): 397-410.

Rood, S.B., Samuelson, G.M., Braatne, J.H., Gourley, C.R., Hughes, F.M.R. and Mahoney, J.M., 2005. Managing river flows to restore floodplain forests. Frontiers in Ecology and the Environment, 3(4): 193-201.

Roy, S., Khasa, D.P., Greer, C.W., 2007. Combining alders, frankiae, and mycorrhizae for the revegetation and remediation of contaminated ecosystems. Canadian Journal of Botany-Revue Canadienne De Botanique, 85(3): 237-251.

Rytter, L., 1996. Grey alder in forestry: a review. Norwegian Journal of Agricultural sciences Supplement 24: 65-84.

Rytter, L., Sennerby-Forsse, L., Alriksson, A., 2000. Natural regeneration of grey alder (Alnus incana (L.) Moench.) stands after harvest. Journal of Sustainable Forestry, 10(3/4): 287-294. 
Scippa, G.S., Trupiano, D., Rocco, M., Di lorio, A., Chiatante, D., 2008. Unravelling the response of poplar (Populus nigra) roots to mechanical stress imposed by bending. Plant Biosystems, 142(2): 401-413.

Tabacchi, E., Gonzalez, E., Corenblit, D., Garofano-Gomez, V., Planty-Tabacchi, A.M., Steiger, J., 2019. Species composition and plant traits: Characterization of the biogeomorphological succession within contrasting river corridors. River Research and Applications, 35(8): 1228-1240.

Thompson, K., Bakker, J.P., Bekker, R.M., 1997. The Soil Seed Banks of North West Europe: Methodology, Density and Longevity Cambridge:. Cambridge University Press, Cambridge, 276 pp. Tockner, K., Malard, F., Ward, J.V., 2000. An extension of the flood pulse concept. Hydrological Processes 14: 2861-2883.

Tockner, K., Stanford, J.A., 2002. Riverine flood plains: present state and future trends. Environmental Conservation, 29(3): 308-330.

Tsolaris, A., Wallace, J. 2002. Analysis of logistic growth models. Mathematical Biosciences 179 (1), 21-55.

Uri, V., Aosaar, J., Varik, M., Becker, H., Ligi, K., Padari, A., Kanal, A., Lohmus, K., 2014. The dynamics of biomass production, carbon and nitrogen accumulation in grey alder (Alnus incana (L.) Moench) chronosequence stands in Estonia. Forest Ecology and Management, 327: 106-117.

Uri, V., Kukumägi, M., Aosaar, J., Varik, M., Becker, H., Soosaar, K., Morozov, G., Ligi, K., Padari, A., Ostonen, I., Karoles, K., 2017. Carbon budgets in fertile grey alder (Alnus incana (L.) Moench.) stands of different ages. Forest Ecology and Management, 396: 55-67.

Uri, V., Lohmus, K., Kiviste, A, Aosaar, J., 2009. The dynamics of biomass production in relation to foliar and root traits in a grey alder (Alnus incana (L.) Moench) plantation on abandoned agricultural land. . Forestry, 82(1): 61-74.

Van Looy, K., Piffady, J., 2017. Metapopulation modelling of riparian tree species persistence in river networks under climate change. Journal of Environmental Management 202: 437-446.

Wilson, S.M., Mason, B., Savill, P., Jinks, R., 2018. Non-native alder species (Alnus spp.). Quarterly Journal of Forestry, 112(3): 163-174.

Wintenberger, C.L., Rodrigues, S., Juge, P., Villar, M., 2017. Survival of pioneer woody seedlings in riverbed: in and ex situ approach of abiotic and biological controlling factors of Populus nigra and Salix alba species. Geomorphologie-Relief Processus Environnement, 23(3): 233-252. 
Wintenberger, C.L., Rodrigues, S., Greulich, S., Breheret, J.G., Juge, P., Tal, M., Dubois, A., Villar, M., 2019. Control of non-migrating bar morphodynamics on survival of Populus nigra seedlings during floods. Wetlands, 39(2): 275-290.

Zanoni, L., Gurnell, A.M., Drake, N., Surian, N., 2008. Island dynamics in a braided river from analysis of historical maps and air photographs. River Research and Applications, 24(8): 1141-1159.

Zen, S., Gurnell, A.M., Zolezzi, G., Surian, N., 2017. Exploring the role of trees in the evolution of meander bends: The Tagliamento River, Italy. Water Resources Research, 53:

doi:10.1002/2017WR020561.

\section{SUPPLEMENTARY MATERIAL}

Growth performance data for $A$. incana from the published literature (Huss-Danell and Lundmark, 1988; Aosaar and Uri, 2008; Johansson, 2005; Uri et al., 2009, 2014, 2017; Krzaklewski et al., 2012, Wilson et al., 2018) were almost entirely stand average measurements obtained from plantations where tree age was known from the date of planting or coppicing, and where tree diameter was measured at breast height (usually $1.3 \mathrm{~m}$ above the ground surface). Despite enormous variations in average annual growth increment between and within geographical areas, some decline was observed with increasing tree age (Figure IA). A reasonably well-defined curved relationship was established between tree height and stem diameter with diameter increasing more rapidly than height as trees aged (Figure IC).

For the Tagliamento, tree ages were only estimated in 2007. When these are plotted against estimated annual growth increments and compared with published data (Figure IB), the Tagliamento estimates fall in the lower half of the published range for trees of the same age. When measurements of tree height and diameter taken within the study reach in 2007 and 2019 are compared with published data, the Tagliamento trees are shorter for the same stem diameter (Figure ID). The Tagliamento data also show far higher variance than the published estimates, but this is probably a result of comparing individual tree measurements from the Tagliamento with published stand averages. The 2007 and 2019 Tagliamento measurements of tree height plotted against stem diameter show a reasonably consistent trend, but the 2019 measurements are generally taken from taller trees. Since the aim in both years was to focus on the largest alder trees, the scatter plot provides evidence of an increase in the size of the largest trees between the two survey dates.

A scatter plot of annual growth rate against tree height (Figure IIA) shows (i) lidar estimates of tree heights (in 2010 and 2013) plotted against lidar estimates of average annual growth rate (estimated, respectively, from the change in height 2005 to 2010 and 2005 to 2013) and (ii) 2007 field estimates of tree heights and average annual growth rates over the life of the tree (calculated by dividing the tree height by its estimated age). Despite the completely different methods used to obtain the lidar and field-based estimates, there is good overlap between the two data sets, although the lidar shows wider variance with some higher estimates of average annual growth increment. Two simple linear regressions of average annual growth increment (dependent variable) against tree height 
(independent variable) for the lidar and field estimates, respectively, showed no significant regression slope $(\mathrm{P}>0.05)$. Quadratic regressions were also not statistically significant, despite the fact that trees generally show lower annual growth increments in their early years and when they approach maturity. This reflects the high variance in the estimates of average annual growth increment.
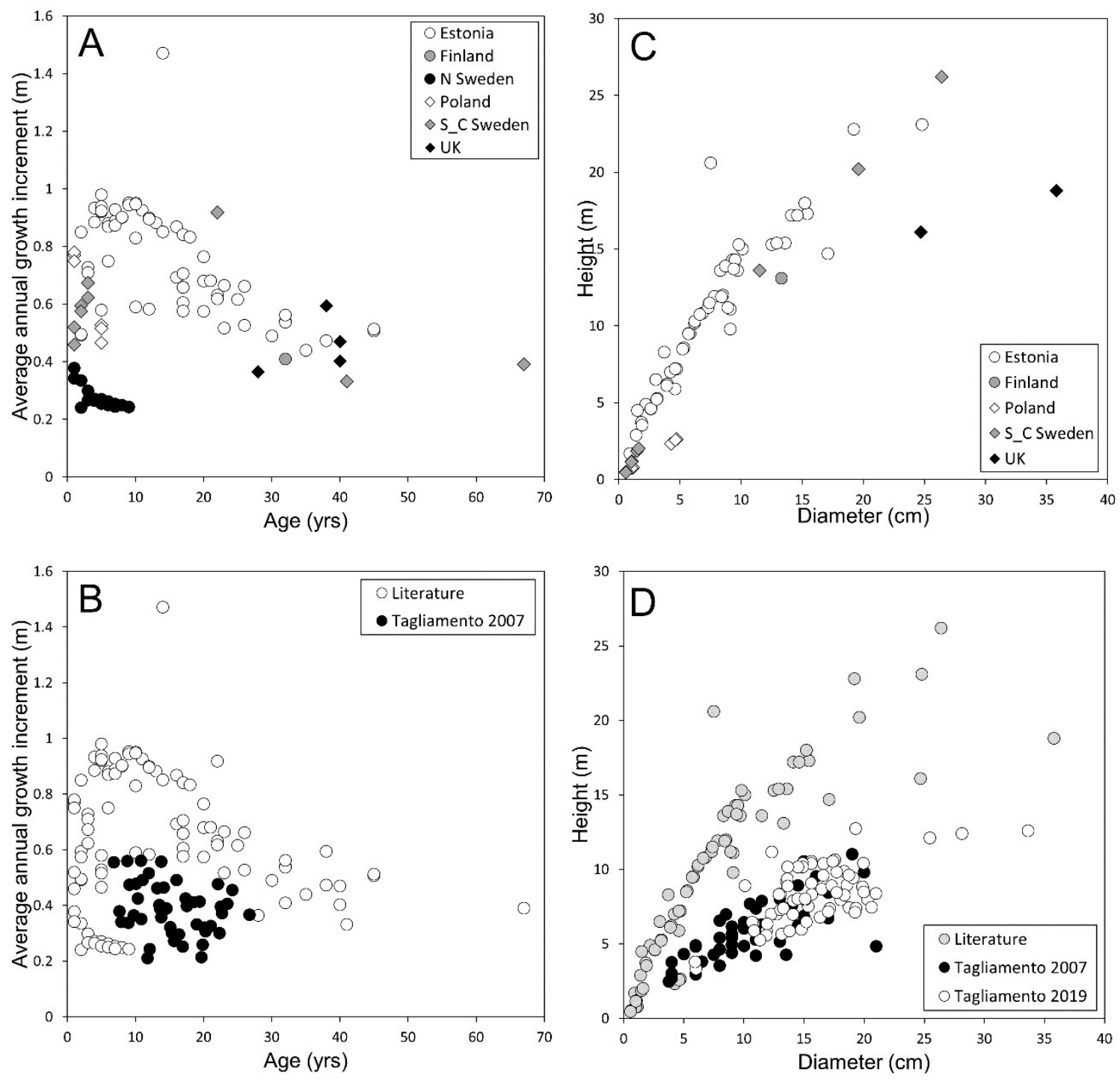

Figure I: Annual growth rates of $A$. incana according to tree age (a) from the published literature and $(B)$ in comparison with field measurements from the Tagliamento in 2007. Height of $A$. incana according to stem diameter (A) from the published literature and (B) in comparison with field measurements from the Tagliamento data in 2007 and 2019. Note the the data from the literature and almost entirely stand averages whereas the data from the Tagliamento are measurements of individual trees. (Data sources: Huss-Danell and Lundmark, 1988; Aosaar and Uri, 2008; Johansson, 2005; Uri et al., 2009, 2014, 2017; Krzaklewski et al., 2012, Wilson et al., 2018) 
In the following analyses, the lidar data is used as the core data source. Therefore, only the lidar estimates of tree height and age were used to develop means of estimating general age-height relationships. Figure IIB shows a scatter plot of the lidar estimates of tree height and age overprinted with a growth curve based on a fixed growth increment of $0.6 \mathrm{~m} . \mathrm{yr}^{-1}$ (dashed line). This rate, which is also overprinted as a dashed line on Figure $5 \mathrm{~A}$, approximates the median and mean lidar estimated growth rates of 0.63 and $0.59 \mathrm{~m} . \mathrm{yr}^{-1}$. This fixed growth rate is compared with a best-fit logistic function (solid line) which emulates the S-shaped curve commonly described by vegetation growth (Tsolaris and Wallace, 2002, Camporeale and Ridolfi, 2006). The fitted curve takes the following form:

$$
\frac{\partial h}{\partial t}=\sigma h\left(1-\frac{h}{h_{M A X}}\right)
$$

where:

$h=$ vegetation height

$\sigma=$ a growth parameter

$h_{\text {MAX }}=$ the maximum height the vegetation can achieve

$t=$ time
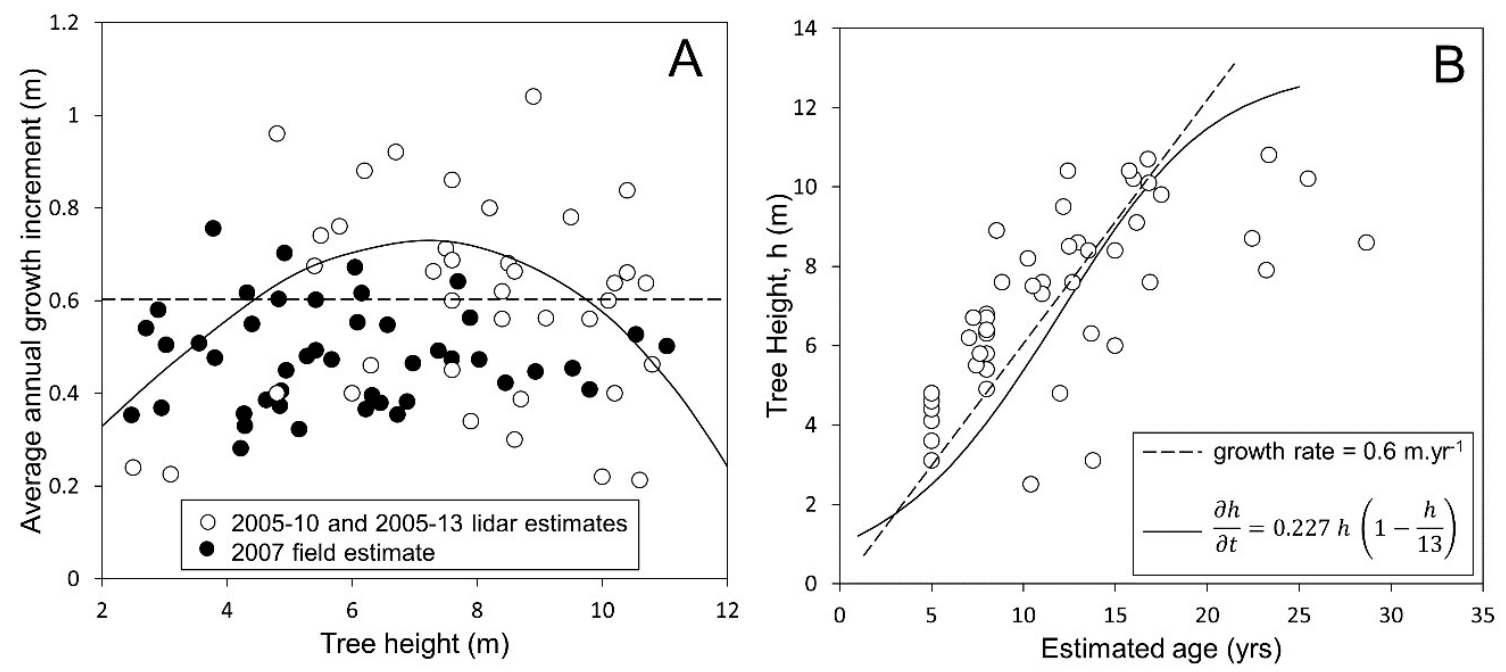

Figure II: Scatter plots of (A) average annual growth increment of $A$. incana estimated from lidar data (white circles) and from field measurements (black circles) plotted against tree height, and (B) lidar estimates of tree height plotted against estimated age (heights in 2010 and 2013, respectively, plotted against estimates of annual growth increment from 2005 to 2010 and from 2005 to 2013). The average annual growth rate (dashed lines) and the relationship between growth rate and height/age (solid curves) shown in A and B were estimated from the lidar data alone (white circles).

In estimating this relationship, we took a value of $13 \mathrm{~m}$ for $h_{\text {MAx }}$ to exceed the $12 \mathrm{~m}$ maximum in the data. We then estimated the value of $\sigma$ by minimising the root mean square error. We used the two relationships shown in Figure 5B to separate observations of alder across areas I, II and III into trees that probably post-dated three of the four flood events in our study period in 1996 (17 years before the 2013 lidar survey), 2000 (13 years before the 2013 lidar survey) and 2004 (9 years before the 
2013 lidar survey). Both relationships give similar results: trees of 17,13 and 9 years of age would be $10.2,7.8$ and $5.4 \mathrm{~m}$ tall following the fixed rate of growth and $10.2,7.6$ and $4.7 \mathrm{~m}$ tall following the $\mathrm{S}$ shaped curve. Therefore, we selected approximate height thresholds of 10,8 and $5 \mathrm{~m}$ to explore spatial distributions of alder of different age. 